\title{
Valuing Black Lives: A Constitutional Challenge to the Use of Race-Based Tables in Calculating Tort Damages
}

\author{
Kimberly A. Yuracko* \& Ronen Avraham**
}

This Article challenges a practice in tort law that is ubiquitous, yet little noticed-namely the use of race-based wage, life expectancy, and work-life expectancy tables when calculating damage awards. The practice results in damage awards that are significantly lower for black victims than for white victims and creates an incentive for potential tortfeasors to allocate risk disproportionately to minority communities. This Article argues that the use of such tables is not only unfair; it is unconstitutional. Specifically, the Article argues that the use of race-based tables to calculate tort damages violates the Equal Protection Clause of the Fourteenth Amendment. The Article goes on to consider the broader implications of this argument and to explain why the move to truly race-neutral damage awards would require even more radical changes to our current tort system.

Introduction

I. How Race-Based Tables are Used....................................................... 330

II. Race-Based Tables as a Racial Classification.

A. Biomarker 338

B. One of Multiple Factors 340

DOI: https://doi.org/10.15779/Z38K649S9M

Copyright (C) 2018 California Law Review, Inc. California Law Review, Inc. (CLR) is a California nonprofit corporation. CLR and the authors are solely responsible for the content of their publications.

* Judd and Mary Morris Leighton Professor of Law, Northwestern Pritzker School of Law.

** Thomas Shelton Maxey Professor of Law, University of Texas School of Law; Professor of Law, Tel Aviv University. The authors are grateful for comments and suggestions on earlier drafts from Michael Barsa, David Dana, Charlotte Crane, Jide Nzelibe and, in particular, Mark Kelman for his close reading of this paper and several helpful conversations. The authors also benefited tremendously from comments and suggestions at faculty workshops at Northwestern Pritzker School of Law, University of Texas School of Law, and George Washington Law School. Professor Yuracko would like to thank her library liaison, Jesse Bowman, for his many contributions as well as Dean Rodriguez and the Judd and Mary Morris Leighton Chair for their support. Professor Avraham would like to thank Dean Farnsworth for his support. 


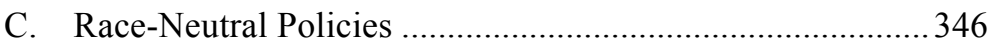

III. Judicial Reliance on Race-Based Tables as State Action ................... 348

A. State Action as State Enforcement........................................351

B. State Action as Furthering Important Interests ......................352

C. State Action as Symbolic Encouragement..............................355

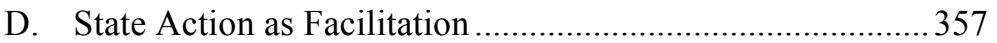

IV. Subjecting Reliance on Race-Based Tables to Strict Scrutiny ..........359

A. Strict Scrutiny as a Nearly Categorical Prohibition..............359

B. Strict Scrutiny as a "Smoking Out" Device...........................360

C. Strict Scrutiny as a Balancing Test .........................................361

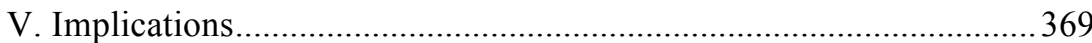

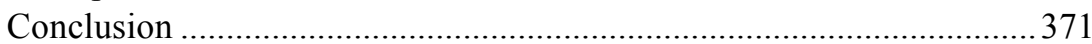

\section{INTRODUCTION}

In 2011, a young couple eagerly expecting the birth of their first child moved into an apartment in Brooklyn, New York, excited to have a new home for their growing family. Their child, a healthy son, was born soon thereafter. One year later, however, the couple received devastating news: a routine medical exam had detected lead in their young son's blood. It turned out that the dust from lead paint in their new home had been quietly poisoning their baby. The family quickly moved out, but permanent damage to the baby's central nervous system had been done. Over the next several years, he would manifest significant cognitive delays as well as severe social and emotional impairments. The baby's mother sued and the landlord was found negligent. ${ }^{1}$

In calculating damages, the critical question for the jury was how much this young child would have earned over the course of his life had he not become injured. In answering this question, experts for both the plaintiff and the defendant took into consideration, albeit to different extents, the fact that the baby was Hispanic. They used this fact to offer lower damage estimates than they would have had the baby been white. ${ }^{2}$ Relying on race-based data to calculate tort damages is, after all, standard practice. ${ }^{3}$ The only thing unusual

1. See Kim Soffen, In One Corner of the Law, Minorities and Women Are Often Valued Less, WASH. POST: WONKBLOG (Oct. 25,2016 , https://www.washingtonpost.com/graphics/business/wonk/settlements [perma.cc/F2RC-MVV2].

2. G.M.M. ex rel. Hernandez-Adams v. Kimpson, 116 F. Supp. 3d 126, 131-35 (E.D.N.Y. 2015).

3. See, e.g., Smith v. United States, No. 08-2375-JWL, 2009 WL 5126623, at *8 (D. Kan. Dec. $18,2009)$ (accepting the average life expectancy for a thirty-year-old black female as the appropriate base for calculating future medical expenses); Rhoades v. Walsh, No. 08-368-P-H, 2009 WL 2600094 , *11 n.24 (D. Me. Aug. 19, 2009) (using the Bureau of Labor Statistics work-life expectancy for a twentysix-year-old white male currently active in the workforce as the appropriate base for calculating future earnings losses); Zuchowicz v. United States, No. 2-91-CV-1033, 1996 WL 776585, at *2 (D. Conn. Nov. 25, 1996) (accepting the average work-life expectancy for a thirty-one-year-old white female as the appropriate base for calculating lost earning capacity), aff' $d, 140$ F.3d 381 (2d Cir. 1998); Morrison 
about the case was that the judge, Jack Weinstein of the Eastern District of New York, refused to allow it. ${ }^{4}$

In tort actions, both plaintiffs and defendants rely on experts to help courts calculate damages. These experts rely in turn on actuarial tables to estimate the victim's life expectancy, work-life expectancy, and expected wages. The life and work-life expectancy tables that experts generally rely upon classify individuals based on both race and sex. ${ }^{5}$ The wage tables they rely upon classify by sex, but experts typically particularize the data by taking race into account as well. ${ }^{6}$ The use of such tables and statistics is particularly important in calculating damage awards for child victims who do not yet have their own educational or work history from which an expert can make a more personalized prediction of future earnings. The result is that because of his race, a black or Hispanic boy will receive significantly less compensation for his lost potential than will a white boy with the same injuries. His life chances, deemed worse to begin with because of his racial status, become certainly worse after his injury because of his smaller damage award. Differences based on sex both complicate and exacerbate differences in compensation.

The use of race-based tables and data not only disadvantages individual tort victims because of their race; it disadvantages racial minority communities more generally. The use of race-based tables creates an incentive for companies to disproportionately allocate risks to minority communities in order to minimize potential tort damages in the future.

It is not that the use of such tables has gone entirely without notice or criticism. Indeed, legal scholars Martha Chamallas and Jennifer Wriggins have

v. State, 516 P.2d 402, 404-05 (Alaska 1973) (endorsing data for white Alaskan females); Powell v. Parker, 303 S.E.2d 225, 228 (N.C. Ct. App. 1983) (affirming race-based statistics for lost income calculation); Johnson v. Misericordia Cmty. Hosp., 294 N.W.2d 501, 528 (Wis. Ct. App. 1980) (affirming race-based statistics for lost income calculation), aff'd, 301 N.W.2d 156 (Wis. 1981); see also United States v. Bedonie, 317 F. Supp. 2d 1285, 1315 (D. Utah 2004) (noting that the court-appointed expert in the case "who has performed thousands of lost income analyses, testified that no one had ever asked him to provide race- and sex-neutral calculations in wrongful death cases"), rev'd on other grounds and remanded sub nom., United States v. Serawop, 410 F.3d 656 (10th Cir. 2005).

4. Kimpson, 116 F. Supp. 3d at 134 (alteration in original) (jury instruction) ("You cannot treat the child as an average Hispanic but [may] only [treat] him with respect to his specific characteristics, such as the mother's degree, where he is living, the kind of family he is coming from, et cetera.... But you cannot say that, for example, Hispanics generally go to college less than others and therefore use that statistic or that analysis or that chart.").

5. U.S. Life Tables provide life expectancy statistics based on sex and racial category (white, black, Hispanic, non-Hispanic white, and non-Hispanic black). See Elizabeth Arias, Melonie Heron \& Betzaida Tejada-Vera, United States Life Tables Eliminating Certain Causes of Death, CDC NAT'L VitAl StAT. ReP., May 31, 2013, at 1; see also Bedonie, 317 F. Supp. 2d at 1315 (noting that the standard way for lawyers and experts to calculate tort damages has been to use race-based estimates of future earnings).

6. See, e.g., Wheeler Tarpeh-Doe v. United States, 771 F. Supp. 427, 455 (D.D.C. 1991) (citing but not relying on testimony from defendant's expert that plaintiff's lost earnings should be calculated by looking at "the average earnings of black men, not those of all men"), rev'd on other grounds, 28 F.3d 120 (D.C. Cir. 1994) (reversing on grounds that the defendant was not liable in tort). 
written strong and compelling critiques of the practice for the past two decades. ${ }^{7}$ A few courts have refused to use race- or sex-based tables for reasons of fairness or public policy. ${ }^{8}$ Special Master of the September 11th Victim Compensation Fund, Kenneth Feinberg, chose to use work-life expectancy tables for men to calculate economic losses for both male and female victims of the 9/11 attacks. $\mathrm{He}$ avoided using blended tables so that neither women nor men would be disadvantaged by women's historically weaker workforce attachment. ${ }^{9}$ In 2008, Judge Jack Weinstein decided McMillan v. City of New York, a case that preceded the G.M.M. v. Kimpson case described above, and became the first federal judge to reject the use of race-based tables on constitutional grounds. ${ }^{10}$ "Equal protection in this context," Judge Weinstein explained, "demands that the claimant not be subjected to a disadvantageous life expectancy estimate solely on the basis of a 'racial' classification." " Seven years later in Kimpson, Judge Weinstein again rejected the use of race-based statistics to calculate tort damages

7. See, e.g., MARTha Chamallas \& JENNIFER B. Wriggins, The MEASURE OF INJURY: RACE, GENDER, AND TORT LAW (2010); Martha Chamallas, Civil Rights in Ordinary Tort Cases: Race, Gender and the Calculation of Economic Loss, 38 LOY. L.A. L. REV. 1435 (2005) [hereinafter Chamallas, Civil Rights in Ordinary Tort Cases]; Martha Chamallas, The September 11th Victim Compensation Fund: Rethinking the Damages Element in Injury Law, 71 TENN. L. REV. 51 (2003) [hereinafter Chamallas, September 11th Fund]; Martha Chamallas, The Architecture of Bias: Deep Structures in Tort Law, 146 U. PA. L. REV. 463 (1998); Martha Chamallas, Questioning the Use of RaceSpecific and Gender-Specific Economic Data in Tort Litigation: A Constitutional Argument, 63 FORDHAM L. REV. 73 (1994) [hereinafter Chamallas, Questioning the Use of Race-Specific and GenderSpecific Economic Data]; Jennifer B. Wriggins, Constitution Day Lecture: Constitutional Law and Tort Law: Injury, Race, Gender, and Equal Protection, 63 ME. L. REV. 264 (2010) [hereinafter Wriggins, Constitutional Law and Tort Law]; Jennifer B. Wriggins, Damages in Tort Litigation: Thoughts on Race and Remedies, 1865-2007, 27 REV. LiTIG. 37 (2007); Jennifer B. Wriggins, Whiteness, Equal Treatment, and the Valuation of Injury in Torts, 1900-1949, in FAULT LINES: TORT LAW AS CULTURAL PRACTICE 156 (David M. Engel \& Michael McCann eds., 2009); see also August McCarthy, The Lost Futures of Lead-Poisoned Children: Race-Based Damage Awards and the Limits of Constitutionality, 15 Geo. MASON U. C.R. L.J. 75 (2004).

8. See, e.g., Bedonie, 317 F. Supp. 2d at 1319 (noting that the constitutional argument made by Martha Chamallas against the use of race and sex in damage calculations "is worth serious attention" but choosing to reject the use of race and sex distinction on a narrower fairness ground); Wheeler Tarpeh-Doe, 771 F. Supp. at 455 (rejecting use of race- and sex-based distinctions in damage calculations on the grounds that "it would be inappropriate to incorporate current discrimination resulting in wage differences between the sexes or races or the potential for any future such discrimination into a calculation for damages resulting from lost wages"); Reilly v. United States, 665 F. Supp. 976, 997 (D.R.I. 1987) (rejecting use of sex-based work-life expectancy projections because of doubts as to "the probative value of such a statistic with respect to twenty-first century women's employment patterns, particularly in light of current, ongoing changes in women's labor force participation rates").

9. Chamallas, September 11th Fund, supra note 7, at 71.

10. McMillan v. City of New York, 253 F.R.D. 247, 248 (E.D.N.Y. 2008).

11. Id. at 255. Judge Weinstein also rejected the use of race-based life expectancy statistics on due process grounds. Id. at 256 ("The legal system does not work fairly and with due process if one class of litigants is unduly burdened in litigation through the application of inappropriate 'race'-based statistics."). 
on constitutional grounds and referred to McMillan for support. ${ }^{12}$ Judge Weinstein held that " $[\mathrm{t}]$ he use of race-based statistics to obtain a reduced damage award - which is now extended to the use of ethnicity-based statistics, to calculate future economic loss-is unconstitutional."13

Nonetheless, the use of race-based tables in the calculation of tort damages remains both standard and largely unnoticed. ${ }^{14}$ Apart from Professors Chamallas and Wriggins, legal academia has largely overlooked the practice. ${ }^{15}$ The

12. G.M.M. ex rel. Hernandez-Adams v. Kimpson, 116 F. Supp. 3d 126 (E.D.N.Y. 2015) (rejecting the use of race-based estimates of expected educational attainment and expected wages).

13. Kimpson, 116 F. Supp. 3d at 152.

14. See supra note 3.

15. Indeed, a review of sixteen casebooks covering torts and remedies revealed that only seven torts and two remedies casebooks even mention the role of race and gender in damage calculations, and among those nine, most give the issue only a few sentences worth of attention. The casebooks reviewed were GeORge C. Christie, Joseph SANDERS \& W. JonAthan CARDi, CASES AND MATERials on THE LAW OF TORTS 1000 (5th ed. 2012) (one paragraph explaining the use of nondeterminative life expectancy tables or work-life tables to establish the period over which the plaintiff will experience diminished capacity and giving an example of a typical jury instruction on this point); DAN B. DOBBS ET AL., THE LAW OF TORTS 23-24 (2d ed. 2011) (one paragraph explaining that life expectancy and work-life tables used as baselines for fixing loss periods "may cause controversy because of different statistical expectancies by race and gender"); MEREDITH J. DUNCAN \& RONALD TURNER, TORTS: A CONTEMPORARY APPROACH ( $2 \mathrm{~d}$ ed. 2012); RICHARD A. EPSTEIN \& CATHERINE M. SHARKEY, CASES AND MATERIALS ON TORTS 858-59 (10th ed. 2012) (one page reporting judicial responses to race- and gender-based statistics in McMillan v. City of New York, 253 F.R.D. 247 (E.D.N.Y. 2008), and CA 100064/02 Migdal Ins. Co. v. Agu-Hana (3) TakSC 3932 (2005) (Isr.)); id. at 859 (one paragraph referencing the Special Master of the September 11th Victim Compensation Fund's use of the tables based on white males for all victims of the attack); WARD FARNSWORTH \& MARK F. GRADY, TORTS: CASES AND Questions (2d ed. 2009); John C. P. Goldberg, ANTHONy J. SEBOK \& BENJAMin C. ZIPURSKY, TORT LAW: RESPONSIBILITIES AND REDRESS 478 (2d ed. 2008) (two paragraphs questioning whether the use of race- or gender-specific statistics violates the Equal Protection Clause, or, even if not, whether courts should adjust for biases in statistics); JAMES A. HENDERSON, JR. ET AL., THE TORTS PROCESS 558-71 (7th ed. 2007) (several pages explaining the difference between actual loss of earnings and loss of earning capacity using cases and life and work-life expectancy tables, and examining the challenges of calculating lost earning capacity for women and the young); CANDACE $\mathrm{S}$. KOVACIC-FleisCHER, JEAN C. LOVE \& GRANT S. NELSON, EQUITABLE REMEDIES, RESTITUTION AND DAMAGes: CASES AND MATERIAls (8th ed. 2011); DOUGlas LAYCOCK, MODERN AMERICAN REMEDIES: CASES AND MATERIALS 211 (4th ed. 2010) (one paragraph noting that gender- and racebased data are often introduced in tort trials, without objections); id. at 211-12 (one paragraph commenting on the insurance industry, where race-based premiums and benefits were generally abandoned while gender-based premiums and benefits persist); DAVID I. LEVINE, DAVID J. JUNG \& Tracy A. ThOMAs, REMEDIES: PubliC AND PRIVATE 528-35 (5th ed. 2009) (four pages analyzing Walker v. Ritchie, 2003 CarswellOnt 10 (Can. Ont. Super. Ct. J.) (WL), in which a Canadian court decided whether the use of gender-neutral statistics for a female plaintiff would be erroneous); $i d$. at 531-33 (two pages contrasting the approach of Canadian courts with American courts in determining lost earning capacity: one court decided to use gender-based wages, Caron v. United States, 410 F. Supp. 378, 398 (D.R.I. 1975); two lined up with Walker, 2003 CarswellOnt 10, United States v. Serawop, 505 F.3d 1112, 1126 (10th Cir. 2007), and Wheeler Tarpeh-Doe v. United States, 771 F. Supp. 427, 455 (D.D.C. 1991); and one reversed appellate court instructions to base a child's lost earning capacity on "some type of average income for persons [in] the community," Greyhound Lines, Inc. v. Sutton, 765 So. 2d 1269, 1276 (Miss. 2000) (en banc) (quoting the court below)); id. at 534-35 (three paragraphs reviewing Judge Weinstein's reasoning in McMillan, 253 F.R.D. at 247); EMILY SHERWIN, THEODORE EISENBERG \& JOSEPH R. RE, AMES, CHAFEE, AND RE ON REMEDIES (1st ed. 2012); ElAINE W. SHOBEN ET AL., REMEDIES CASES AND PROBLEMS (5th ed. 2012); RoBERT S. THOMPSON ET AL., REMEDIES: 
constitutional argument offered by Judge Weinstein in McMillan and Kimpson is insightful and bold, but it is brief, and other courts have not yet followed it. What is needed is a sustained and comprehensive analysis of the constitutionality of the use of such tables in tort award calculations. ${ }^{16}$ This Article seeks to provide such an argument in order to empower other judges to follow Judge Weinstein in rejecting the use of race-based tables in calculating tort damages.

This Article proceeds in five Parts. Part I describes both the use and effect of race-based tables in tort actions. Parts II-IV analyze the constitutional permissibility of their use under the Equal Protection Clause of the Fourteenth Amendment. Specifically, Part II argues that the use of race-based tables is indeed a racial classification for the purposes of equal protection analysis. Part III argues that reliance by judges and juries on the use of such tables in calculating tort awards constitutes state action. Part IV argues that the use of race-based tables fails to satisfy the demands of strict scrutiny. After concluding that the use of race-based tables is unconstitutional, the Article then turns in Part $\mathrm{V}$ to consider, in somewhat sobering terms, the likely results of rejecting racebased tables. This Part explores which racial inequities would, and would likely not, be eliminated by a move away from race-based tables. We conclude that while rejecting the use of race-based tables is constitutionally necessary, such rejection alone is not sufficient to achieve a tort system that neither reflects nor encourages race discrimination in the award of damages.

I.

\section{HOW RACE-BASED TABLES ARE USED}

In calculating tort damages, judges and juries rely on the testimony of experts, generally forensic economists, who provide estimates for the court of how much it would take to make the victim whole. ${ }^{17}$ The plaintiff, who has

DAMAGES, EQUITY, AND RESTITUTION (4th ed. 2009); AARON D. TWERSKI \& JAMES A. HENDERSON, JR., TORTS: CASES AND MATERIALS 667-68 (2d ed. 2008) (two paragraphs discussing various difficulties calculating future damages especially for young female plaintiffs); FRANK J. VANDALL, Ellen Wertheimer \& MARK C. RAHDERT, TORTS: CASES AND PROBlems (3rd ed. 2011). One notable exception is DOMINICK VETRI ET AL., TORT LAW AND PRACTICE (5th ed. 2016), which does include an extensive discussion of the issue.

16. See Anthony J. Sebok, Judge Jack Weinstein's Ruling Barring the Use of Race in Calculating the Expected Lifespan of a Man Seeking Tort Damages: An Isolated Decision, or the Beginning of a Legal Revolution?, FINDLAW (Oct. 22, 2008), http://writ.news.findlaw.com/sebok/20081022.html [https://perma.cc/A5F2-SG3G] (noting that "Judge Weinstein's brief reference to [the constitutional] argument — notwithstanding the law review articles he cites - needs to be developed more fully").

17. See Thomas R. Ireland, The Role of the Forensic Economist in Damage Assessment for Personal Injuries, in Measuring Loss, in MEASURING LOSS IN CATASTROPHIC INJURY CASES 15 (Kevin S. Marshall \& Thomas R. Ireland eds., 2006); see also Ruzzi v. Butler Petroleum Co., 588 A.2d 1, 10 (Pa. 1991) (holding that the presentation of expert testimony was appropriate to assist the jury in calculating the plaintiff's lost earning capacity); Moody v. Blanchard Place Apartments, 793 So. 2d 281, 300-01 (La. Ct. App. 2001) (providing an example of how damage calculations are usually presented in court). 
successfully proven the defendant's liability, is entitled to be compensated for the lost earnings, the medical costs, and the pain and suffering caused by the defendant's negligence. Critical to this calculation are three factors: expected wages, work-life expectancy, and life expectancy. In reaching estimates for all three factors, economists rely on tables and data that explicitly distinguish and define people based on race.

Wage data is, of course, critical to calculating a victim's lost future earnings. When the plaintiff does not have an earnings record that is reflective of the individual's projected earnings - either because the plaintiff is a child without any earnings record or because she is a young adult whose current job does not reflect her ultimate career-experts rely on the Bureau of Labor Statistics' annual wage tables as a starting point. The wage tables provide average national wage statistics for males and females broken down by occupation. ${ }^{18}$ Experts then routinely adjust wage-rate estimates based on the plaintiff's race. ${ }^{19}$

Work-life expectancy data is also important for calculating lost future earnings. Given that the United States has no mandatory retirement age, courts typically instruct juries to determine a plaintiff's future earnings for the duration of his or her work-life expectancy. Tables again provide the starting point for experts' determinations of work-life expectancy. ${ }^{20}$ Although various tables are available, ${ }^{21}$ many experts rely on work-life expectancy tables provided by the Bureau of Labor Statistics (BLS) or on tables established by economists Gary Skoog, James Ciecka, and Kurt Krueger. The BLS tables provide work-life expectancies for certain racial categories, for example white, "black and other,"

18. See U.S. DEP'T OF LABOR, BUREAU OF LABOR STATISTICS, MEDIAN WEEKLY EARNINGS of Full-Time Wage and Salary Workers by Detailed OCCupation and SEX (2017), http://www.bls.gov/cps/cpsaat39.pdf [https://perma.cc/U24R-4S76].

19. See, e.g., Wheeler Tarpeh-Doe v. United States, 771 F. Supp. 427 (D.D.C. 1991) (defendant's expert calculated lost future earnings for plaintiff injured shortly after birth by looking to average earnings of black men, not all men), rev'd on other grounds, 28 F.3d 120 (D.C. Cir. 1994); Athridge v. Iglesias, 950 F. Supp. 1187, 1193 (D.D.C. 1996) (plaintiff's expert calculated future earnings for a fifteen-year-old white male by looking to Department of Commerce, Bureau of Census statistics for the mean salary of white male college graduates), aff'd, Nos. 96-7261, 89CV01222, 1997 WL 404854 (D.C. Cir. June 30, 1997).

20. Just as with life expectancy calculations, either side can present evidence that adjusts the statistical work-life expectancy up or down, depending on characteristics particularized to that individual. See, e.g., Earl v. Bouchard Transp. Co., 735 F. Supp. 1167, 1176 (E.D.N.Y. 1990) (reducing the plaintiff's work-life expectancy from the statistical work-life expectancy because he testified as to his pre-accident intended retirement date, which was several years earlier than his statistical work-life expectancy).

21. For alternative tables see Thomas R. Ireland, Why Markov Process Worklife Expectancy Tables are Usually Superior to the LPE Method, 16 J. LEGAL ECON. 95, 100-01 (2010); VOCATIONAL ECON., INC., CALCULATION OF WORKLIFE EXPECTANCY USING THE LIFE, PARTICIPATION, EMPLOYMENT METHOD (2006), http://www.vocecon.com/resources/ftp/data/lpecalc.pdf [https://perma.cc/HE79-KEP4]. 
and for each sex within those racial categories. ${ }^{22}$ The Skoog, Ciecka, and Krueger tables provide work-life expectancies for each sex at various levels of educational attainment. ${ }^{23}$

Life expectancy data in turn is critical for calculating a plaintiff's future medical expenses and pain and suffering damages. Experts' starting point for determining the life expectancy of the plaintiff is generally the most recent version of the federal government's US Life Tables, which provides life expectancy statistics for the population as a whole, for each gender, and for certain racial categories (white, black, Hispanic, non-Hispanic white, and nonHispanic black). ${ }^{24}$ Traditionally, the estimates experts have provided to juries have reflected these categories. ${ }^{25}$

In some cases, experts seek to refine life expectancy estimates by accounting for specific injuries and health conditions of the plaintiff. To do so, many forensic economists apply "relative mortality ratios" 26 to reflect life expectancy reductions due to disability or health factors such as paraplegia or smoking. Often these relative mortality ratios, too, are particularized to race and sex, thus further compounding race- and sex-based disparities in damage award calculations. $^{27}$

The use of such tables reflects not only professional practice, but, in some states, official preference. Indeed, two states, Georgia and Rhode Island, have passed statutes that actually guarantee the admissibility in court of particular life expectancy and work-life expectancy tables that distinguish among people based

22. U.S. DeP'T of Labor, Bureau of Labor Statistics, Bulletin 2254, Worklife ESTIMATES: EFFECTS OF RACE AND EDUCATION tbls.A-2, A-5 (1986), https://www.bls.gov/opub/reports/worklife-estimates/archive/worklife-estimates-1986.pdf [https://perma.cc/HEP9-YRYV].

23. See, e.g., Edward M. Foster \& Gary R. Skoog, The Markov Assumption for Worklife Expectancy, 17 J. FoRENSIC ECON. 167 (2004); Kurt V. Krueger, Gary R. Skoog \& James E. Ciecka, Worklife in a Markov Model with Full-Time and Part-Time Activity, 19 J. FORENSIC ECON. 61 (2006); Gary R. Skoog, James E. Ciecka \& Kurt V. Krueger, The Markov Process Model of Labor Force Activity: Extended Tables of Central Tendency, Shape, Percentile Points, and Bootstrap Standard Errors, 22 J. FoRENSIC ECON. 165 (2011); Gary R. Skoog \& James E. Ciecka, The Markov (IncrementDecrement) Model of Labor Force Activity: Extended Tables of Central Tendency, Variation, and Probability Intervals, 11 J. LEGAL ECON. 23 (2001).

24. See Elizabeth Arias, Melonie Heron \& Jiaquan Xu, United States Life Tables, 2012, CDC NAT'L VitAL STAT. REP., Nov. 28, 2016, at 1; see also T.W. ANDERSON, LIFE EXPECTANCY IN COURT: A TEXTBOOK FOR DOCTORS AND LAWYERS 21 (2002) (using US Life Tables as a foundation for life expectancy calculation); Richard B. Singer, How to Prepare a Life Expectancy Report for an Attorney in a Tort Case, 37 J. INS. MED. 42, 43 (2005) (using US Life Tables as a foundation for life expectancy calculation).

25. See Singer, supra note 24 , at 43 (describing use of US Life Table to calculate life expectancy).

26. The Relative Mortality Ratio represents the relative chances a person is likely to die in any year, as compared to the general population. For example, an RMR of two means the person is twice as likely to die in any year, an RMR of three means the person is three times as likely to die in any year, and so on. See Robert J. Thornton \& Frank Slesnick, New Estimates of Life Expectancies for Persons with Medical Risks, 10 J. FORENSIC ECON. 285, 285 (1997).

27. See id. 
on race and sex. ${ }^{28}$ Moreover, four states have pattern jury instructions that express a preference for life expectancy tables that distinguish along racial lines. $^{29}$

From a public policy and social justice perspective, the use of race-based tables in calculating tort damages is troubling. Most directly, the use of racebased tables leads to racial disparities at the level of the individual tort victim. Black victims receive lower damage awards than they would have if they were white. ${ }^{30}$ The magnitude of these effects is most transparent in cases in which courts choose to depart from the norm and use racially blended instead of racebased tables.

Consider, for example, the case of United States v. Bedonie. ${ }^{31}$ Bedonie involved claims for restitution under the Mandatory Victim Restitution Act in two unrelated homicide cases-one involving a twenty-one-year-old Native American man with a high school education who was killed by a drunk driver, and the other a three-month-old Native American girl who was killed by her father. ${ }^{32}$ In an unusual move, the court ordered its own expert to calculate damages in the standard way-namely taking into account the plaintiffs' race and sex - as well as using tables that blended rather than differentiated based on race and sex. ${ }^{33}$ The difference in the calculations is illuminating.

For the man, the expert calculated projected earnings at $\$ 433,562$ after adjusting for race and sex of a high school graduate. By comparison, when the expert calculated expected earnings by looking at all American workers with a high school diploma (without regard to race and sex), the result was $\$ 744,442$, approximately 72 percent higher. ${ }^{34}$ For the baby girl, the expert calculated projected earnings at $\$ 171,366$ after adjusting for race and sex of a non-high school graduate. By comparison, when the expert calculated unadjusted expected earnings for all non-high school graduates, the result was $\$ 308,633$,

28. See GA. CODE ANN. § 24-14-44 (2017); 9 R.I. GEN. LAwS § 9-19-38 (2017).

29. Those states are Kansas, Kentucky, Michigan, North Dakota, and Tennessee. See Kan. Civil Pattern Jury Instructions $\S 171.45$ (2016); Ky. Wrongful Death Actions $\S 13: 3$ (2012-13 ed.) (Life Expectancy Tables); N.D. Civil Pattern Jury Instructions $§ 70.47$ (2012) (Personal Injury); 8 Tenn. Civil Pattern Jury Instructions, app.C (2012).

30. It is worth noting, however, that a move to fully blended expected wage tables would not necessarily help black men. While including white men would benefit black men, including female workers might disadvantage them. In Wheeler Tarpeh-Doe v. United States, for example, the court refused to use a race-based table when calculating lost income for a baby boy of mixed African and Caucasian ancestry. The court rejected the defendant's argument that average black male earnings were the appropriate measure of the victim's future earnings and instead used the average wages for all persons unadjusted for race and sex. Doing so, however, resulted in a lowering of the victim's award from projected earnings of $\$ 1,008,434$ when adjusted for race and sex, to projected earnings of $\$ 882,692$ when unadjusted for race or sex. See 771 F. Supp. 427, 455 (D.D.C. 1991), rev'd on other grounds, 28 F.3d 120 (D.C. Cir. 1994).

31. 317 F. Supp. 2d 1285 (D. Utah 2004).

32. Id. at 1288-92.

33. Id. at 1315.

34. Id. at $1314-15$ and 1315 n.132. 
approximately 80 percent higher. ${ }^{35}$ While the court did not engage in a full constitutional analysis of the use of race- or sex-based tables, it did note that "it was concerned about possible constitutional and other problems in relying on race and sex assumptions" in calculating lost earnings for the victims. ${ }^{36}$ As a result of these concerns, the court rejected the use of race- and sex-based tables. It awarded $\$ 446,665$ for the death of the man - a figure that significantly reduced the unadjusted estimate to take into account the relatively low wages and irregular work patterns typical of those in the man's chosen field of art. It awarded $\$ 325,751$ for the death of the baby girl, which included the $\$ 308,633$ estimate from the court's expert combined with the value of a stipend the plaintiff would have received from her tribe. ${ }^{37}$

Consider also G.M.M. v. Kimpson, the case described in this Article's introduction, in which a baby boy suffered from lead poisoning in his family's apartment. G.M.M.'s ethnicity played a role in the experts' damage calculations in two distinct ways. First, expected earnings of Hispanic men were lower than those for white men at every level of education. ${ }^{38}$ Second, Hispanic men were significantly less likely to achieve advanced degrees than were white men. Plaintiff's expert mitigated the effect of general ethnicity data by focusing heavily on the characteristics of G.M.M.'s own immediate and extended family, and in particular their high levels of academic achievement. ${ }^{39}$ By contrast, defendant's expert put significant weight on the fact that only 2.1 percent of Hispanic men held a masters degree or better. ${ }^{40}$ The effect of these choices was that the plaintiff estimated G.M.M's lost earnings at $\$ 3.4$ million, while the defendant estimated his lost earnings at $\$ 1.5$ million. ${ }^{41}$ Although Judge Weinstein, relying on his prior opinion in McMillan v. City of New York, ${ }^{42}$ ultimately barred both sides' experts and the jury from considering G.M.M.'s ethnicity, ${ }^{43}$ this case illustrates how big an impact race and ethnicity considerations can have on individual awards. ${ }^{44}$

Moreover, the use of race-based tables not only has an ex post effect on compensation, it also has an ex ante effect on risk allocation. Specifically, the use of race-based tables creates public and private incentives to allocate risk disproportionately to racial minority communities so as to minimize potential

35. Id. at $1314-116,1321,1322,1316$ n.134

36. Id. at 1314.

37. Id. at $1314-15,1321-12,1316$ n.134. 2015).

38. See G.M.M. ex rel. Hernandez-Adams v. Kimpson, 116 F. Supp. 3d 126, 145 (E.D.N.Y.

39. Id. at 132 .

40. Id. at 135 .

41. See Soffen, supra note 1.

42. McMillan v. City of New York, 253 F.R.D. 247 (E.D.N.Y. 2008).

43. Kimpson, 116 F. Supp. 3d at 134.

44. The jury ended up awarding G.M.M. $\$ 2$ million in damages, and after the defendant appealed, the case settled for $\$ 1.9$ million. See Soffen, supra note 1. 
future liability. ${ }^{45}$ Consider, for example, a delivery company that sends thousands of trucks through American neighborhoods every day. The company knows that, statistically speaking, it should expect to have five accidents per day. It might even know which drivers are most likely to be involved in accidents, perhaps those who have been truck drivers for fewer than five years or those who are over age fifty-five. It would be economically rational for the company to concentrate its routes, as much as possible, through black neighborhoods rather than white neighborhoods and to disproportionately assign its highest-risk drivers to black neighborhoods. The result is both more activity and more accidents in black neighborhoods as compared to white neighborhoods.

The incentive to allocate risk based on the anticipated financial costs of the harm has not, of course, gone unnoticed by those in positions of power. Indeed, in a leaked 1991 memo from the World Bank, Lawrence Summers, its Chief Economist at the time, explained that because damages for health impairments due to pollution reflect lost earnings, the World Bank should actually encourage more "dirty industries" in less developed countries. Summers wrote:

Just between you and me, shouldn't the World Bank be encouraging MORE migration of the dirty industries to the LDCs [Less Developed Countries]? ... The measurements of the costs of health impairing pollution depend on the foregone earnings from increased morbidity and mortality. From this point of view a given amount of health impairing pollution should be done in the country with the lowest cost, which will be the country with the lowest wages. I think the economic logic behind dumping a load of toxic waste in the lowest wage country is impeccable and we should face up to that. ${ }^{46}$

While American companies and local governments are not so explicit about targeting minority and poor communities, evidence showing correlations between risk and minority communities suggests that such targeting may in fact be taking place. A 2004 study, for example, found that the risk of accidents for chemical facilities in heavily African-American counties is twice as high as the risk in other counties, ${ }^{47}$ and a Harvard study conducted for the City of New York in 1990 documented higher numbers of adverse actions caused by negligence in

45. See Chamallas, Civil Rights in Ordinary Tort Cases, supra note 7, at 1441 ("[B]ecause it is cheaper to injure poor minority children, there is less incentive for defendants to take measures to clean up toxic hazards in the neighborhoods most affected by lead paint."); Michael I Meyerson \& William Meyerson, Significant Statistics: The Unwitting Policy Making of Mathematically Ignorant Judges, 37 PEPP. L. REV. 771, 808 (2010) ("[W] hen damages for injuring members of minority groups are lowered, the legal regimen [has] the perverse result of encouraging torts against them.").

46. Memorandum from Lawrence Summers, Chief Economist for the World Bank, to the World Bank (Dec. 12, 1991), http://www.whirledbank.org/ourwords/summers.html [https://perma.cc/5CBWYLYH].

47. See M.R. Elliott, Y. Wang, R.A. Lowe \& P.R. Kleindorfer, Environmental Justice: Frequency and Severity of US Chemical Industry Accidents and the Socioeconomic Status of Surrounding Communities, 58 J. EPIDEMIOLOGY \& COMMUNITY HEALTH 24 (2004). 
hospitals serving minority communities. ${ }^{48}$ There is also a history of legislative bodies disproportionately siting hazardous waste dumps in minority communities. $^{49}$

Perhaps less obviously, the use of race-based tables both embeds the effects of racial discrimination into individual tort awards and actually channels past levels of racial discrimination into predictions about the future. Consider, for example, a three-year-old boy injured in a car accident. Even though this child, given his young age, has not himself yet suffered direct racial discrimination in the workplace, and even though racial discrimination may be expected, hopefully, to diminish over the course of his life, projections about his future earnings, as well as his life expectancy and work-life expectancy, will incorporate the levels of racial discrimination suffered by black men who came of age generations before him. The result is not only that the boy's compensation will be tainted by racial discrimination, but that it will be tainted by a level of racial discrimination that the boy would likely not have actually suffered had he not become injured. ${ }^{50}$

Finally, the use of race-based tables essentializes individuals based on their race. Moreover, it essentializes them not just in terms of some shared physical attribute or even in terms of a shared past cultural experience, but in a more fundamentally troubling way. The use of race-based tables allows courts to make guesses about the future proclivities of individuals - their professional interests, personal health habits, and workforce attachment - all based on their racial group identification. Certainly, this raises concerns about accuracy. Predictions about individual behavior based on group membership are necessarily imprecise. But such is the case with all actuarial data as applied to discrete individuals. The more particular and potent concerns raised here relate to racial salience and stigma. Proclivity predictions based on race threaten to stigmatize members of those groups who have become characterized by less socially desirable attitudes, aptitudes, and behaviors. By reinforcing the salience of race, proclivity predictions also make it more difficult to recognize individual outliers, of which

48. The study analyzed different possible risk factors associated with suffering from an "adverse event" (injuries resulting from medical interventions) and found that "blacks had higher rates of adverse events and adverse events resulting from negligence." Issues Relating to Medical Malpractice: Hearing Before the Subcomm. on Health of the H. Comm. on Ways and Means, 103d Cong. 29 (1993) (citing Harvard Med. Practice Study, Patients, Doctors, and LaWyers: MEdical InJuRy, MALPRACTICE LiTIGATION, AND PATIENT COMPENSATION IN NEW YORK (1990)). Although the study found that "these differences overall were not significant," it did note that "higher rates of adverse events and negligent events were found in hospitals that served a higher proportion of minority patients." Id.

49. See generally, Robert D. Bullard \& Beverly Wright, Disastrous Response to Natural and Man-Made Disasters: An Environmental Justice Analysis Twenty-Five Years After Warren County, 26 UCLA J. ENVTL. L. \& POL'Y 217 (2008).

50. However, as we discuss infra in Part IV, even if this particular reality of how tort tables operate could be "fixed," perhaps by including in the actuarial models a prediction of diminishing racial discrimination over time, the constitutional infirmities caused by the use of race-based tables would not be cured. 
as a statistical matter there are necessarily many,${ }^{51}$ and increase the likelihood of racial discrimination at the individual and social level.

In short, the use of race-based tables to calculate tort damages is ubiquitous. Moreover, from a policy and social justice perspective its effects are troubling and directly counter to society's commitment to dismantle its legacy of racial discrimination. Yet the question remains as to whether the use of race-based tables is also unconstitutional. In the next three Sections, we address whether the use of race-based tables violates the Equal Protection Clause of the Fourteenth Amendment. The Equal Protection Clause applies only to state action, and the level of scrutiny applicable to the state action at issue depends on the nature of the classification at issue, with classifications based on race necessarily subject to the highest level of scrutiny. ${ }^{52}$ As a result, equal protection clause analysis requires considering: first, whether the use of race-based tables constitutes a racial classification; second, whether reliance on race-based tables constitutes state action; and third, whether the use of such tables can pass the heightened degree of scrutiny to which we argue it is necessarily subject. It is to these questions that we now turn.

II.

\section{Race-BASEd TABles as a RaCial Classification}

In discussing police reliance on race-based suspect descriptions, Professor Albert Alschuler has observed that " $[t]$ o people who use the English language in the ordinary way, questioning blacks and not whites does appear to classify by race. ${ }^{, 53}$ Yet, as a matter of practice, courts do not treat police reliance on racebased suspect descriptions as racial classifications for the purposes of constitutional analysis. ${ }^{54}$ When a court relies on race to determine the appropriate compensation for a child who has been killed or seriously injured in a tort case, common sense too sees a classification based on race. This Section will consider several possible arguments for why using race in the calculation of tort awards should not be treated as a race-based classification for the purposes of equal protection analysis in order to determine whether there is any plausible reason why law and common sense should in this context too diverge. Specifically, this

51. See infra note 215 and accompanying text. Although a very small percentage of individuals of any race will in fact match the predictions associated with their race, such race-based predictions obscure intra-race variability and provide a sticky baseline for damage calculations which mitigates the extent of individualized variation.

52. See Suzanne A. Kim, Suzette Richards \& Rachel L. Jensen, Equal Protection, 1 Geo. J. GENDER \& L. 213, 218-224 (2000).

53. Albert W. Alschuler, Racial Profiling and the Constitution, 2002 U. CHI. LEGAL F. 163, 185 (2002).

54. See Brown v. City of Oneonta, 221 F.3d 329, 337-38 (2d Cir. 2000); see also R. Richard Banks, Race-Based Suspect Selection and Colorblind Equal Protection Doctrine and Discourse, 48 UCLA L. REV. 1075, 1077-78 (2001) ("No court has treated law enforcement reliance on a race-based suspect description as a racial classification warranting strict scrutiny under the Equal Protection Clause.”). 
Section considers whether judicial reliance on race-based tables can avoid constitutional scrutiny as a racial classification because the tables describe physical biomarkers, because race-based metrics are used along with non-racebased information to calculate award amounts, or because reliance on such tables reflects a neutral practice applied to all tort victims regardless of race.

\section{A. Biomarker}

What seems critical to the legal conclusion that a race-based suspect description is not, for equal protection purposes, a racial classification is the perception that a suspect description reflects a relevant, objective, physical truth about a particular individual. It does not make predictions about the proclivities or future conduct of group members generally. ${ }^{55}$ As a result, race-based suspect descriptions are seen as unlikely to either stereotype and stigmatize racial groups or to encourage future discrimination against members of the group.

As Professor Sheri Lynn Johnson has explained, "the use of race to identify a particular perpetrator" is not a racial classification for constitutional purposes because "[a]lthough the suspect's race is noted and weighed in the decision to detain, no generalizations about the characteristics, behavior, or appropriate treatment of the racial group are employed." ${ }^{, 56}$ Professor R. Richard Banks similarly notes that "[p]hysical descriptions are considered a wholly unproblematic cataloguing of visually important yet morally irrelevant characteristics such as eye and hair color, to be distinguished from a racial profile that points toward an individual's deeper qualities, judging who people are rather than merely how they appear.",57

Certainly, one might disagree with courts about whether police reliance on race-based suspect descriptions should be free from constitutional scrutiny. ${ }^{58}$

55. See, e.g., Oneonta, 221 F.3d at 337 (explaining that the black residents subjected to questioning as a result of a race-based suspect description were questioned on the "altogether legitimate basis of a physical description given by the victim of a crime"), reh'g denied, 235 F.3d 769 (2d Cir. 2000).

56. Sheri Lynn Johnson, Race and the Decision to Detain a Suspect, 93 YALE L.J. 214, 237, 243 (1983). For a broader discussion of why courts and legal scholars view statistical evidence with more suspicion than individualized evidence, even when the two are probabilistically equivalent, see David Enoch \& Talia Fisher, Sense and "Sensitivity": Epistemic and Instrumental Approaches to Statistical Evidence, 67 STAN. L. REV. 557 (2015).

57. Banks, supra note 54, at 1092-93.

58. Alternatively, one might conclude that the treatment of race-based suspect descriptions is a legal aberration flowing from practical necessity rather than sound legal argument. See United States v. Waldon, 206 F.3d 597, 604 (6th Cir. 2000) (explaining that "[c]ommon sense dictates that, when determining whom to approach as a suspect of criminal wrongdoing, a police officer may legitimately consider race as a factor if descriptions of the perpetrator known to the officer include race"); see also Cartnail v. State, 753 A.2d 519, 530 (Md. 2000) (explaining that "[i]n looking at the description of the suspects, undoubtedly physical characteristics, such as race, gender, ethnicity, hair color, facial features, age, body build, or apparel of a suspect permits winnowing of innocent travelers"). Of course, even if a race-based suspect description were treated as a racial classification, its use would not automatically be unconstitutional. It would, however, be subject to strict scrutiny. Judge Calabresi, dissenting from the Second Circuit's denial of the plaintiff's petition for rehearing en banc in Oneonta, suggested that the 
Indeed, Professor Banks contends that because the use of racial biomarkers in suspect descriptions leads to unequal burdens based on race, the use of such biomarkers should be subject to strict scrutiny. ${ }^{59}$ Professor Alschuler likewise emphasizes the real and relative burdensomeness of police reliance on racebased suspect descriptions. "When an officer, relying on a witness description, restricts the liberty of black men in green coats and not the liberty of white men in green coats," Alschuler explains, "this officer differentiates by race."

Regardless of its persuasiveness generally, the argument that descriptions of physical biomarkers are not racial classifications provides no constitutional shield for judicial reliance on race-based tort tables. Unlike suspect identifications, race-based tables do not describe any particular individual. They only describe groups. Moreover, rather than describing an objective truth, they serve instead as predictors of future behavior and preferences based precisely on one's group membership. As such, their use is likely to stereotype group members and channel discrimination against members of the group into the future. For example, race-based wage tables and work-life tables predict the kind of work people will choose, the success they will have at it, and their attachment to it based on their group membership and the opportunities members of their group have had in the past. As such, these tables reinforce racial group stereotypes and channel discrimination from the past into the future both through the damages particular tort victims receive and through social risk allocations to minority communities.

At first glance, life expectancy data might look more "objective"apparently revealing some biological or genetic truth. ${ }^{61}$ In fact, however, racial differences in life expectancy reflect, at least to some degree, a social history of segregation and discrimination. ${ }^{62}$ Moreover, even if such data were an accurate description of the past, it is being used to predict the future, which is necessarily more uncertain. Finally, even if such data could provide an accurate description of future life expectancies, the data describes a group, rather than any particular individual. As a result, the data necessarily encourages discrimination based on

reason courts rejected outright the idea that race-based suspect descriptions are racial classificationsrather than acknowledging them as such and subjecting them to strict scrutiny — was to avoid weakening strict scrutiny. Calabresi explained that "[i]f an action is deemed a racial classification, it is very difficult, under the Supreme Court precedents, ever to justify it. And, were such justification made easier in cases of police following a victim's description, the spillover to other racial classification contexts would be highly undesirable." Brown v. City of Oneonta, 235 F.3d 769, 786 (2d Cir. 2000).

59. See Banks, supra note 54, at 1080 (arguing that both race-based suspect descriptions and racial profiles "constitute intentional uses of race in a manner that disparately burdens innocent members of certain racial minority groups"); see also Alschuler, supra note 53, at 183.

60. Alschuler, supra note 53, at 183.

61. Indeed, in McMillan, Judge Weinstein rejected the use of race-based life expectancy statistics but permitted the use of sex-based life expectancy statistics, presumably because he thought that differences based on sex reflected real biological differences while those based on race did not. McMillan v. City of New York, 253 F.R.D. 247, 249-55 (E.D.N.Y. 2008).

62. See infra note 128 
group membership - even as to those individuals for whom the group data is nonpredictive.

The logic for treating race-based suspect descriptions as constitutionally unproblematic simply does not apply to the use of race-based tables in torts cases. Race-based tables do not describe a relevant individual biomarker free of social meaning and social consequences. Instead, race-based tables reveal nothing about the particular tort victim but reflect and reinforce the very groupbased social meanings and stereotypes that the Equal Protection Clause targets.

\section{B. One of Multiple Factors}

A second argument for why judicial reliance on race-based tables does not constitute a racial classification is that the tables merely insert race as one factor into an overall analysis that includes many other factors as well. Indeed, tort damages are not determined solely on the basis of the victim's race. ${ }^{63}$ Under this view, the consideration of other factors - such as socioeconomic status and family educational background-prevents the consideration of race from constituting a racial classification that could trigger strict scrutiny under the Equal Protection Clause.

Two early racial profiling cases gave this argument some traction in the Fourth Amendment context. In United States v. Brignoni-Ponce, for example, the border patrol-engaged in a routine roving search for people entering the country illegally from Mexico - stopped the defendant's car based solely on the grounds that the occupants appeared to be Mexican. ${ }^{64}$ In affirming the defendants' Fourth Amendment challenge to the search of the vehicle, the Supreme Court held that race alone could not justify police stops of cars driving northbound on an interstate highway in southern California. ${ }^{65}$ The Court went on to say, however, that race, or in this case, Mexican appearance, was a relevant factor that the border patrol could consider along with other factors - such as the driver's behavior, the make of the car, or the number of passengers - in deciding which cars to stop for questioning. ${ }^{66}$

In United States v. Martinez-Fuerte, the Supreme Court took the argument even further. ${ }^{67}$ Martinez-Fuerte involved the selective referral of cars stopped by

63. As Martha Chamallas explains, in wrongful death actions, "[t]he typical instruction on this issue asks the jury to consider: 'the age, sex and physical and mental characteristics of the child, supplemented, when available, with evidence as to the position in life and earning capacity of the parents, as well as evidence as to the rendition, if any, of household services by the minor." Chamallas, Questioning the Use of Race-Specific and Gender-Specific Economic Data, supra note 7, at 95 (quoting Eakelbary v. Nipper, Summit App. No. 9476 (May 21, 1980)).

64. United States v. Brignoni-Ponce, 422 U.S. 873, 875 (1975).

65. Id. at 884-87 (holding that respondents" "apparent Mexican ancestry" alone could not provide the reasonable cause necessary under the Fourth Amendment to justify the stop).

66. Id. at $885-86$.

67. United States v. Martinez-Fuerte, 428 U.S. 543, 556 (1976). 
the border patrol to a secondary inspection area for further questioning. ${ }^{68}$ The Supreme Court distinguished such checkpoint stops from the roving patrol stops at issue in Brignoni-Ponce noting that they were less burdensome and frightening for motorists. ${ }^{69}$ The Court then went on to hold that there was no racial classification and no constitutional violation if police referred motorists to a secondary inspection area "largely on the basis of apparent Mexican ancestry.",70

Yet later profiling cases have rejected the idea that the consideration of factors in addition to race could somehow shield police use of a racial profile from heightened scrutiny. In United States v. Montero-Camargo, the Ninth Circuit faced the question of whether consideration of Hispanic appearance along with several other factors was sufficient to give border control agents the reasonable suspicion necessary to stop the defendants' cars. ${ }^{71}$ In ruling that the use of racial appearance was not appropriate, the court made clear that consideration of race did not lose its constitutionally problematic nature simply by being mixed and mingled with nonracial considerations. ${ }^{72}$

The Montero-Camargo court did not go so far as to say that consideration of racial appearance by border patrol agents would always and automatically be unconstitutional under the Fourth Amendment or trigger strict scrutiny under the Fourteenth Amendment. ${ }^{73}$ The court did, however, emphasize that reasonable suspicion under the Fourth Amendment requires particularized or individualized suspicion of the defendant. ${ }^{74}$ Given the high number of Hispanic individuals living in the area of Southern California where the stops took place, the fact of Hispanic appearance could not contribute to or bolster the particularized suspicion necessary to stop the defendants. The "danger of stigmatic harm" and the risk of reinforcing "notions of racial inferiority" was too great. ${ }^{75}$ Law enforcement could consider race only to the extent that it described a particular individual being sought because of past acts. ${ }^{76}$ It could not be used, either alone or along with other factors, to predict the proclivities of particular groups of individuals. $^{77}$

68. Id. at $546-47$.

69. Id. at 558 .

70. Id. at 563 .

71. United States v. Montero-Camargo, 208 F.3d 1122, 1129-31 (9th Cir. 2000).

72. Id. at 1135

73. Id.

74. See id. at 1132 (quoting United States v. Rodriguez, 976 F.2d 592, 596 (9th Cir. 1992)) (alteration in original) ("As we put it in Rodriguez, "[w]e are not prepared to approve the wholesale seizure of miscellaneous persons . . . in the absence of well-founded suspicion based on particular, individualized, and objectively observable factors which indicate that the person is engaged in criminal activity."').

75. Id. at 1135 (internal quotation marks omitted).

76. Id. at 1132 .

77. Id. at 1135 ("[A]t this point in our nation's history, and given the continuing changes in our ethnic and racial composition, Hispanic appearance is, in general, of such little probative value that it may not be considered as a relevant factor where particularized or individualized suspicion is required."). The Ninth Circuit distinguished and minimized the importance of the Supreme Court's decision in 
The Sixth Circuit in United States $v$. Taylor seemed to take an even stronger stance against the inclusion of race in a law enforcement profile - at least in nonborder patrol cases. ${ }^{78}$ Taylor involved a stop on suspicion of drug possession at an airport in Memphis, Tennessee. The Sixth Circuit affirmed the district court's dismissal of the plaintiff's motion to suppress evidence, but noted that had the plaintiff presented evidence showing that "law enforcement officers at the Memphis Airport implemented a general practice or pattern that primarily targeted minorities for consensual interviews, or that they had incorporated a racial component into the drug courier profile," his allegations "would have given rise to due process and equal protection constitutional implications cognizable by [that] court." ${ }^{, 79}$ The fact that race might be only one component among others promoting a search did not negate the constitutional implications of the racial classification being made.

The idea that racial considerations become less problematic constitutionally when mixed with nonracial considerations also has a foothold in voting rights cases. Beginning with Justice O'Connor's decision in Shaw v. Reno, the Supreme Court has held that the intentional race-based drawing of district lines triggers strict scrutiny only if plaintiffs prove that race was the predominant factor used to draw district lines. ${ }^{80}$ In Hunt v. Cromartie, for example, the Supreme Court responded to the plaintiffs' racial gerrymandering claim by explaining that strict scrutiny would only apply if the plaintiffs could show that race was the " "predominant factor' motivating the legislature's districting decision." ${ }^{, 81}$ Citing its prior cases of Shaw v. Hunt ${ }^{82}$ and Miller v. Johnson, ${ }^{83}$ the Court further explained that " $[\mathrm{t}] \mathrm{o}$ carry their burden, appellees were obliged to show ... that 'the legislature subordinated traditional race-neutral districting principles, including but not limited to compactness, contiguity, and respect for political

Brignoni-Ponce by explaining that in arriving at its "brief dictum consisting of only half a sentence . . . suggesting that ethnic appearance could be relevant, the Court relied heavily on nowoutdated demographic information." Id. at 1132; see also United States v. Taylor, 956 F.2d 572, 582 (6th Cir. 1992) (en banc) (Keith, J., dissenting) ("The use of an immutable characteristic as the basis of suspicion for criminal activity is patently unconstitutional, and the notion that DEA agents and like state personnel can consider race in carrying out its duties is nothing short of outrageous and cannot be permitted.").

78. Taylor, 956 F.2d at 578-79.

79. Id.

80. Shaw v. Reno, 509 U.S. 630, 642 (1993) (citation omitted) ("[A]ppellants appear to concede that race-conscious redistricting is not always unconstitutional. That concession is wise."); see also Samuel Issacharoff, The Constitutional Contours of Race and Politics, 1995 SUP. CT. REV. 45, 45 (1995) ("The precise contours of this new standard [announced by Justice O'Connor in Shaw v. Reno] were well concealed, but clearly they involved some notions of excessive reliance on race as manifested through grotesquely configured district line-drawing.").

81. Hunt v. Cromartie, 526 U.S. 541, 547 (1999).

82. Shaw v. Hunt, 517 U.S. 899, 905 (1996).

83. Miller v. Johnson, 515 U.S. 900, 916 (1995). 
subdivisions or communities defined by actual shared interests, to racial considerations. ${ }^{\prime, 84}$

The predominant-factor test seems largely to be a pragmatic response to the peculiarities of the voting context in which it is difficult practically and impermissible legally for state legislators to draw district lines without considering race at all. As the majority in Miller explained, "[r]edistricting legislatures will, for example, almost always be aware of racial demographics ... in the redistricting process." ${ }^{, 5}$ Moreover, Sections 2 and 5 of the Voting Rights Act actually require legislators to be mindful of race when drawing district lines. ${ }^{86}$ Indeed, the redistricting plan creating two majority-black districts, which prompted the lawsuit in Shaw, was drawn only after the Attorney General denied preclearance under Section 5 to an earlier district map providing only one majority minority district. ${ }^{87}$

While the proof needed to satisfy the predominant-factor test remains uncertain, the harm the test was meant to guard against has been clearly spelled out. ${ }^{88}$ Justice O'Connor explained in Shaw that the kind of racial harms the Equal Protection Clause was intended to protect against were those stemming from group essentializing and stereotyping. ${ }^{89}$ As the Supreme Court elaborated in Miller, "When the State assigns voters on the basis of race, it engages in the offensive and demeaning assumption that voters of a particular race, because of their race, 'think alike, share the same political interests, and will prefer the same candidates at the polls." "'90 It is this harm that the Equal Protection Clause was intended to protect against.

In the voting rights context then, race can be considered, but not in a way that reflects or reinforces essentialized ways of thinking about the members of different racial groups. It is the manner in which race is considered and its impact, rather than the mere presence of other factors, that saves the state action from triggering strict scrutiny.

84. Hunt, 526 U.S. at 547; see also Bush v. Vera, 517 U.S. 952 (1996) (finding a voting district plan violated the Equal Protection Clause because race was the predominant consideration in creating the district lines).

85. Miller, 515 U.S. at 916.

86. Section 5 of the Voting Rights Act of 1965, 52 U.S.C.A. $§ 10304$ (West 2017), prohibits a jurisdiction subject to its provisions from making changes to its voting practices without obtaining "either a judgment from the United States District Court for the District of Columbia declaring that the proposed change "does not have the purpose and will not have the effect of denying or abridging the right to vote on account of race or color' or administrative preclearance from the Attorney General." Shaw v. Reno, 509 U.S. 630, 634 (1993). Section 2 "of the Voting Rights Act forbids any State [from] impos[ing] specified devices or procedures that result in a denial or abridgment of the right to vote on account of race or color." Id. at 662 n.2.

87. Id. at 642 .

88. See Issacharoff, supra note 80 , at 53.

89. Reno, 509 U.S. at 647 (explaining that it is an "impermissible racial stereotype[]" to assume that individuals of the same race share the same political interests and preferences simply because of their race).

90. Miller, 515 U.S. at 911-12 (quoting Reno, 509 U.S. at 647). 
In other contexts, however, the Supreme Court has not followed the predominant-factor test, but has made clear that any consideration of race triggers strict scrutiny. Consider, for example, the Supreme Court's rejection in McCleskey v. Kemp of the petitioner's Equal Protection and Eighth Amendment challenges to Georgia's capital sentencing process. ${ }^{91}$ The defendant relied on statistics to show that the race of the victim and the race of the defendant affected the likelihood that a defendant would be sentenced to the death penalty. ${ }^{92}$ The defendant in McCleskey lost because the Court concluded that he did not show that race played a role in his particular case. ${ }^{93}$ Yet his burden, the Court made clear, was not to show that race was the "but for" cause of his death sentence, or even that it was a predominant factor in his death sentence, but only that it was a factor. " "[T] prevail under the Equal Protection Clause," the Court explained, "[the defendant] must prove that the decisionmakers in his case acted with discriminatory purpose. He offers no evidence specific to his own case that would support an inference that racial considerations played a part in his sentence." $"$ As Professors Samuel Gross and Katherine Barnes emphasize, " $[\mathrm{N}] \mathrm{o}$ American court would ever uphold a death sentence under the Equal Protection Clause if the prosecutor admit[ted] that she asked for the death penalty in part because of the defendant's race, regardless of any nonracial factors that entered into that decision." 96

In affirmative action cases as well, the Court has made clear that any consideration of race constitutes a racial classification that triggers strict scrutiny. As Professor Alschuler has pointed out with regard to government contractor cases, "under the affirmative action plans the Supreme Court has subjected to strict scrutiny and held invalid, no one awarded government-funded contracts on the basis of race alone." ${ }^{97}$ The same has been true of the Court's analysis of affirmative action plans in education. In Regents of the University of California v. Bakke, for example, the Medical School of the University of California at Davis set up a special admissions program designed to increase the number of racial minorities admitted to the school. ${ }^{98}$ The program considered

91. McCleskey v. Kemp, 481 U.S. 279, 320 (1987).

92. Id. at 286 .

93. Id. at 292-93. Julian A. Cook, Jr. and Mark S. Kende have argued that the Court was more willing to use statistics to infer discriminatory purpose in voting cases than in death penalty cases. While this does seem true, what is most important for our purposes is that the Court also imposed a different and lower racial causation burden in death penalty cases as opposed to voting rights cases. See Julian A. Cook, Jr. \& Mark S. Kende, Color-Blindness in the Rehnquist Court: Comparing the Court's Treatment of Discrimination Claims by a Black Death Row Inmate and White Voting Rights Plaintiffs, 13 T.M. COOLEY L. REV. 815 (1996).

94. McCleskey, 481 U.S. at 292-93.

95. Id.

96. Samuel R. Gross \& Katherine Y. Barnes, Road Work: Racial Profiling and Drug Interdiction on the Highway, 101 MICH. L. REV. 651, 740 (2002).

97. Alschuler, supra note 53, at 179.

98. Regents of the Univ. of Cal. v. Bakke, 438 U.S. 265, 277 (1978). 
race as one factor among others in determining admissions decisions. ${ }^{99}$ Yet despite the fact that race was only one factor among many governing admissions decisions for those in the special admissions program, the Court made clear that "all legal restrictions which curtail the civil rights of a single racial group are immediately suspect" and "courts must subject them to the most rigid scrutiny." $" 100$

The Supreme Court followed the same analysis twenty-five years later when it considered the University of Michigan Law School's affirmative action plan in Grutter v. Bollinger. ${ }^{101}$ The school considered race, along with a wide range of other factors, in making admissions decisions. ${ }^{102}$ Even the plaintiffs' expert conceded at trial that "race [was] not the predominant factor in the Law School's admissions calculus." 103 Nonetheless, the Court subjected the admissions process to strict scrutiny. ${ }^{104}$ Indeed, the issue before the Court was not whether there was a racial classification, but whether the school could show that its admissions process was narrowly tailored to achieve a compelling state interest. $^{105}$

Race-based tables in tort cases operate much like racial profiles. They stereotype individuals and make predictions about individual preferences and proclivities based on group membership. Following the logic of the more recent racial profiling cases, there is no reason that the consideration of factors other than race in the tort context should negate the constitutional implications of considering race.

There is, likewise, no reason to transfer the predominant-factor test from the voting rights context to tort law. The consideration of race is not a social

99. Id. at 275 .

100. Id. at 291 (internal quotation marks omitted) (quoting Korematsu v. United States, 323 U.S. 214, 216 (1944)). In Village of Arlington Heights v. Metropolitan Housing Development Corp., a zoning case decided by the Supreme Court the following year, the Court emphasized that the Equal Protection Clause "does not require a plaintiff to prove that the challenged action rested solely on racially discriminatory purposes." Instead, "[w]hen there is a proof that a discriminatory purpose has been a motivating factor in the decision, this judicial deference is no longer justified." 429 U.S. 252, 265-66 (1977).

101. Grutter v. Bollinger, 539 U.S. 306, 322 (2003).

102. Id. at 318-20.

103. Id. at 320 .

104. Id. at 327 .

105. Id. at 322. The Supreme Court ultimately upheld the law school's admissions plan, finding that the school had a compelling interest in attaining a diverse student body and the admissions program was narrowly tailored to serve that interest. Id. at 343. In Gratz v. Bollinger, by contrast, the Court held that the same university's undergraduate admissions policy did not survive strict scrutiny because the use of race in that policy was not narrowly tailored. The Court in that case held that "the University's policy, which automatically distributes 20 points, or one-fifth of the points needed to guarantee admission, to every single 'underrepresented minority' applicant solely because of race, is not narrowly tailored to achieve the interest in educational diversity that respondents claim justifies their program." Gratz v. Bollinger, 539 U.S. 244, 270 (2003). Similarly, in Fisher v. University of Texas at Austin, 136 S. Ct. 2198 (2016), the Supreme Court subjected the University of Texas's admission process to strict scrutiny even though it used race only as one factor to admit only approximately 25 percent of the class. 
exigency in tort cases, as it is in voting rights cases. Race consciousness in calculating tort awards is not necessary to ensure that the state is acting so as to dismantle rather than reinforce traditional racial hierarchies. Quite the contrary, when race-based tables and data are used, they serve to essentialize tort victims in precisely the way that concerned the Court in voting rights cases.

Using race-based tables to calculate tort damages assumes that individuals of the same race will share the same professional interests, adopt the same lifestyle habits, and prioritize work and family in the same way. These are precisely the kind of "offensive and demeaning assumption[s]"106 about individuals that the Court made clear should constitute racial classifications in the voting rights cases. As a result, considerations of race in tort cases should be treated, as they are in death penalty and affirmative action cases, as always constituting racial classifications - even when race is considered along with other factors.

\section{Race-Neutral Policies}

A third argument for why the use of race-based tables in tort cases does not constitute a racial classification is that their use reflects a race-neutral policy. Tort damages are calculated for all victims, at least in part, by plugging the victim's race into life, work-life, and wage tables and seeing what numbers come out. The practice and process of using the tables, the argument goes, is race neutral and hence is not a racial classification.

The Second Circuit in Brown v. Oneonta seemed to rely to some extent on such a rationale when it refused to subject police reliance on race-based suspect descriptions to strict scrutiny. ${ }^{107}$ According to the court, the defendants' policy of relying on suspect descriptions to structure police investigations "was raceneutral on its face; their policy was to investigate crimes by interviewing the victim, getting a description of the assailant, and seeking out persons who matched that description." 108 Even though in Oneonta the police only targeted black people for questioning, the investigative practice that led to their targeting was itself race neutral — namely following suspect descriptions.

This argument is, in effect, one about the appropriate degree of generality with which courts should view and analyze a challenged practice. Many policies that distinguish based on race, when viewed at the discrete level of the individual, can also be framed, at a higher level of abstraction, as neutral policies of general applicability. Yet it cannot be, and is not the case, that equal protection scrutiny rises or falls based simply on the level of generality with which a state frames and describes a particular practice.

106. Miller v. Johnson, 515 U.S. 900, 912 (1995).

107. Brown v. City of Oneonta, 221 F.3d 329, 338 (2d Cir. 2000).

108. Id. at 337. 
Indeed, the Supreme Court regularly looks behind a defendant's facially neutral framing to find racially disparate treatment. In Loving v. Virginia, for example, the Supreme Court summarily dismissed the state's argument that its anti-miscegenation statute did not constitute a racial classification because the law imposed the same restrictions and penalties upon members of every racial group. ${ }^{109}$ The Court looked instead to what the law actually meant for individuals seeking to marry and concluded that "[t]here can be no question but that Virginia's miscegenation statutes rest solely upon distinctions drawn according to race." ${ }^{110}$ The statutes at issue, the court noted, worked so as to treat individuals differently depending on their race and to "proscribe generally accepted conduct if engaged in by members of different races." ${ }^{, 111}$ Although all racial groups might have been prohibited from miscegenation, on an individual level the antimiscegenation law meant that a white person could marry a white person but a black person could not. At the individual level, the law involved a clear racial distinction and thus triggered strict scrutiny. ${ }^{12}$

In Shelleyv. Kraemer too, the respondents sought to frame the case as being about the state's neutral policy of enforcing private covenants. ${ }^{113}$ Respondents urged the Court to conclude "that since the state courts stand ready to enforce restrictive covenants excluding white persons from the ownership or occupancy of property covered by such agreements, enforcement of covenants excluding colored persons may not be deemed a denial of equal protection of the laws to the colored persons who are thereby affected." 114 Yet the Court refused to treat neutral framing as a shield against Fourteenth Amendment challenges. ${ }^{115}$ Instead, the Court insisted on looking more discretely at the effect state enforcement would have on the rights and opportunities of individuals. "The rights established [by the Fourteenth Amendment]" the Court emphasized, "are personal rights." 116 What was most important for determining the appropriate degree of scrutiny was the way in which the state's conduct affected the actual rights and opportunities of individuals. ${ }^{117}$ "Because of the race or color of these petitioners they have been denied rights of ownership or occupancy enjoyed as

109. Loving v. Virginia, 388 U.S. 1, 7-8 (1967) ("[T]he State argues that the meaning of the Equal Protection Clause, as illuminated by the statements of the Framers, is only that state penal laws containing an interracial element as part of the definition of the offense must apply equally to whites and Negroes in the sense that members of each race are punished to the same degree.”). In fact, the Virginia law did not treat all racial groups equally since the state law prohibited white people from marrying anyone other than a white person while permitting members of other racial groups to marry someone from any racial group other than white. See Loving, 388 U.S. 1.

110. Id. at 11 .

111. Id.

112. Id.

113. Shelley v. Kraemer, 334 U.S. 1 (1948).

114. Id. at 21 .

115. Id. at 21-22.

116. Id. at 22 .

117. Id. 
a matter of course by other citizens of different race or color." 118 As a result, state enforcement of racially restrictive covenants triggered strict scrutiny and "denied petitioners the equal protection of the laws." 119

In the tort context, it is similarly clear that, at the individual level, the use of race-based tables leads to differently sized damage awards for victims because of their race. Though the practice of relying on actuarial tables can be described in neutral terms, these tables identify, classify, and judge individual victims based on race. In legal terms, this constitutes a racial classification.

In short, there is no jurisprudential reason to deviate from the commonsense conclusion that the use of race-based tables to calculate tort awards constitutes a race-based classification for the purposes of the Fourteenth Amendment. Of course, in order for this racial classification to trigger strict scrutiny, it must be the product of state action. In the next Section, we turn to the question of whether judicial reliance on expert testimony using race-based tables constitutes state action.

III.

\section{Judicial RELIANCE On RACE-BASED TABles as State ACTION}

The Equal Protection Clause of the Fourteenth Amendment provides that "[n]o State shall ... deny to any person within its jurisdiction the equal protection of the laws." ${ }^{120}$ The clause does not apply to classifications and distinctions made by private individuals. ${ }^{121}$

State action doctrine is neither clear nor simple. ${ }^{122}$ There is no single onoff switch whereby constitutional scrutiny is triggered or avoided. State action doctrine is more of a morass - a set of rather loose doctrines and rules that are highly dependent on the context and consequences of each particular case. ${ }^{123}$ As

118. Id. at $20-21$.

119. Id. at 20

120. U.S. CONST. amend. XIV, $\S 1$.

121. Henry C. Strickland, The State Action Doctrine and the Rehnquist Court, 18 HASTINGS CONST. L.Q. 587, 592-93 (1991) (alteration of "[state]" in original) (quoting Shelley, 334 U.S. at 13) ("A litigant seeking the protection of [the Fourteenth Amendment] guarantees must establish that the allegedly unconstitutional conduct complained of 'may fairly be said to be that of the [state].' If the conduct is not that of the state, then it cannot be unconstitutional-however wrongful it may bebecause the Constitution applies only to state action."); see also Flagg Bros., Inc. v. Brooks, 436 U.S. 149,157 (1978) (citations omitted) ("While as a factual matter any person with sufficient physical power may deprive a person of his property, only a State or a private person whose action 'may be fairly treated as that of the State itself' may deprive him of 'an interest encompassed within the Fourteenth Amendment's protection."').

122. Indeed, Charles Black famously described state action doctrine as "a conceptual disaster area." Charles L. Black, Jr., The Supreme Court 1966 Term Foreword: "State Action," Equal Protection, and California's Proposition 14, 81 HARV. L. REV. 69, 95 (1967); see also G. Sidney Buchanan, A Conceptual History of the State Action Doctrine: The Search for Governmental Responsibility, 34 HOUS. L. REV. 333, 338 (1997) (providing a "conceptual history, in its multifaceted manifestations" of the state action doctrine).

123. It is not surprising then that the state action doctrine has generated a great deal of scholarship, criticism, and disagreement about its contours. See, e.g., Lawrence A. Alexander, Cutting the Gordian 
the Supreme Court explained in Burton v. Wilmington Parking Authority, "to fashion and apply a precise formula for recognition of state responsibility under the Equal Protection Clause is an 'impossible task' which 'This Court has never attempted.' Only by sifting facts and weighing circumstances can the nonobvious involvement of the State in private conduct be attributed its true significance." 124

Nonetheless, it is clear that if a judge were to award a black tort victim lesser damages than a white tort victim because of her or his own racial bias, the conduct would constitute state action. ${ }^{125}$ The jury too is "an entity that is a quintessential governmental body, having no attributes of a private actor." ${ }^{126} \mathrm{As}$ a result, from an equal protection perspective, it does not matter if the source of racial bias in civil litigation is a judge or jury. In either case, there is state action.

What makes reliance on race-based tables in tort cases potentially trickier is that the judge and jury are not acting on their own biases when they award black victims lesser damages than similarly injured white victims. Instead, they are relying on the testimony of expert witnesses as to the life expectancy, expected earnings, and expected work-life duration of tort victims. Moreover, such testimony does not reflect the private bias of the individual expert, but the social reality revealed by actuarial tables.

Nonetheless, there is good reason to view the social reality of the actuarial tables as reflective, at least in part, of both private and public racial bias. With regard to wage data, for example, while findings vary widely across studies depending largely on the methodology used, most attribute at least some of the race-based wage differential to intentional discrimination. ${ }^{127}$ At least some of the

Knot: State Action and Self-Help Repossession, 2 HASTINGS CONST. L.Q. 893, 893-95 (1975) ("“T]he search for state action is a fundamentally misguided quest. State action is present in every lawsuit because the laws of a state are being applied."); Don Herzog, The Kerr Principle, State Action, and Legal Rights, 105 MiCH. L. REV. 1, 41 (2006) ("[D]espite the familiar cadences of the case law, it's a mistake to think that the state action inquiry and the appraisal of claimed violations of legal rights are two independent queries, with the first serving as a threshold inquiry to the second. That's why one can be a state actor for some purposes, but not others."); Erwin Chemerinsky, Rethinking State Action, $80 \mathrm{Nw}$. U. L. REV. 503, 505-07 (1985) (suggesting abandonment of the doctrine, in part, because of its incoherence).

124. Burton v. Wilmington Parking Auth., 365 U.S. 715, 722 (1961) (citation omitted).

125. A judge acting in her official capacity is clearly a state actor, and her decisions constitute state action under the Equal Protection Clause. See, e.g., Edmonson v. Leesville Concrete Co., 500 U.S. 614,614 (1991) (noting that the trial system is "administered solely by government officials, including the trial judge, himself a state actor"); Pulliam v. Allen, 466 U.S. 522, 540 (1984) ("Subsequent interpretations of the Civil Rights Acts by this Court acknowledge Congress' intent to reach unconstitutional actions by all state actors, including judges.").

126. Edmonson, 500 U.S. at 624.

127. See, e.g., Marianne Bertrand \& Senhil Mullainathan, Are Emily and Greg More Employable than Lakisha and Jamal? A Field Experiment on Labor Market Discrimination, 94 AM. ECON. REV. 991, 992 (2004) (finding that "[a]pplicants with [w]hite names need to send about 10 resumes to get one callback whereas applicants with African-American names need to send about 15 resumes"); Kevin Lang \& Michael Manove, Education and Labor Market Discrimination, 101 AM. ECON. REV. 1467, 1495 (2011) (finding using statistical discrimination models that "the results in this paper cast doubt on an emerging consensus that the origins of the black-white wage differential lie in premarket rather than labor-market factors"); Derek A. Neal \& William R. Johnson, The Role of Premarket Factors in Black- 
racial disparity in life expectancy and, correspondingly, work-life expectancy, is also likely due to racial discrimination in the health care provided to black people as compared to white people. ${ }^{128}$ Therefore, when judges or juries award black victims lower damage awards than white victims who are similarly injured because of their reliance on experts' race-based wage, life, and work-life expectancy data, they give effect to and reinforce private prejudice and biasnot their own or even that of the expert, but that of society more generally.

The question then becomes whether there is state action for the purposes of equal protection analysis when a judge or jury relies on expert testimony that reflects and reports a social reality tainted by historical race discrimination. Notwithstanding the morass that is state action doctrine, ${ }^{129}$ it is clear that at least some state enforcement of private prejudice will be considered state action for the purposes of the Fourteenth Amendment.

In Shelley v. Kraemer, the Supreme Court held that state enforcement of racially restrictive private covenants violated the Equal Protection Clause of the federal Constitution. ${ }^{130}$ Although there has been much discussion in the years following Shelley about its scope ${ }^{131}$-and indeed its continued viability ${ }^{132}$ - the case's core holding that there are some forms of private conduct which the state simply cannot with constitutional impunity authorize or enforce has in fact been

White Wage Differences, 104 J. POL. ECON. 869, 871 (1996) (concluding based on a statistical discrimination model that "[w]hile we find some evidence of labor market discrimination . . . the disadvantages young black workers now face in the labor market arise mostly from the obstacles they faced as children in acquiring productive human capital"); Devah Pager, Bruce Western \& Bart Bonikowski, Discrimination in a Low-Wage Labor Market: A Field Experiment, 74 AM. Soc. REV. 777, 785 (2009) (finding in an audit study that "a black applicant has to search twice as long as an equally qualified white applicant before receiving a callback or job offer from an employer").

128. See Sidney D. Watson, Race, Ethnicity and Quality of Care: Inequalities and Incentives, 27 AM. J.L. \& MED. 203 (2001) (describing historical segregation and discrimination in the health care system and tying it to persistent racial disparities in medical treatment and health outcomes even after formal and overt racial discrimination in healthcare came to an end in the early 1960s); INST. OF MED. OF THE NAT'L ACADS., UNEQUAL TREATMENT: CONFRONTING RACIAL AND ETHNIC DISPARITIES IN HEALthCARE 5 (Brian D. Smedley et al. eds., 2003) ("The majority of studies ... find that racial and ethnic disparities remain even after adjustment for socioeconomic differences and other healthcare access-related factors.").

129. See Burton, 365 U.S. at 722; see also Black, supra note 122, at 95.

130. Shelley v. Kraemer, 334 U.S. 1, 20 (1948) ("[I]n granting judicial enforcement of the restrictive agreements in this case, the States have denied petitioners the equal protection of the laws and ... therefore, the action of the state courts cannot stand.").

131. See, e.g., United Egg Producers v. Standard Brands, Inc., 44 F.3d 940, 943 (11th Cir. 1995) (limiting Shelley to "the racial discrimination context"); Golden Gateway Ctr. v. Golden Gateway Tenants Ass'n, 29 P.3d 797, 810 (Cal. 2001) (citations omitted) ("Although the United States Supreme Court has held that judicial effectuation of a racially restrictive covenant constitutes state action, it has largely limited this holding to the facts of those cases."); see also Edward Brunet, Arbitration and Constitutional Rights, 71 N.C. L. REV. 81, 111 (1992) (stating that Shelley "has been interpreted as limited to its facts"); Frank Askin, Free Speech, Private Space, and the Constitution, 29 RUTGERS L.J. 947, 948 (1948) (explaining that "the doctrine of Shelley v. Kraemer appears to have been limited by most courts to the enforcement of racially discriminatory provisions").

132. See Mark D. Rosen, Was Shelley v. Kraemer Incorrectly Decided? Some New Answers, 95 CALIF. L. REV. 451, 454 (2007) (arguing that Shelley "has not survived"). 
repeated in numerous cases. ${ }^{133}$ In the following Sections we consider the four most common interpretations of Shelley and its progeny to determine whether judicial reliance on race-based tables constitutes state action.

\section{A. State Action as State Enforcement}

Read most broadly, Shelley can be viewed as eviscerating the distinction between state and private action rendering all private conduct—or at least all that which the state is called upon to recognize and enforce - subject to constitutional constraints. ${ }^{134}$ Several courts and scholars have recognized, if not necessarily endorsed, this interpretation of Shelley. As Ronald Krotoszynski explains: "Shelley has proven controversial because it could be read to mean that any court involvement in an essentially private dispute satisfies the state action requirement. Under this interpretation of Shelley, court involvement will transform private contract or property disputes into matters subject to the constitutional restrictions applicable to the government's behavior." "135 Judge Skelley Wright in Edwards v. Habib expressed a similarly expansive view of the Court's holding in Shelley. ${ }^{136}$ In Wright's view, "There can now be no doubt that the application by the judiciary of the state's common law, even in a lawsuit between private parties, may constitute state action which must conform to the constitutional strictures which constrain the government... This may be so even where the court is simply enforcing a privately negotiated contract." 137

Clearly this broad reading of Shelley is not the legal reality. ${ }^{138}$ As a practical matter, states may authorize private individuals to engage in conduct that the state may not itself engage in directly. Catholic schools may teach the catechism

133. See Herzog, supra note 123, at 46 (cataloguing a vast array of cases in which courts have held state deference to, and enforcement of, wholly private prejudices to be unconstitutional state action).

134. Whether the state has simply recognized a particular private right or actually been called upon to enforce the right in court seems immaterial since to have a right means, by definition, that the state will protect one's expression of it. See Maimon Schwarzschild, Value Pluralism and the Constitution: In Defense of the State Action Doctrine, 1988 SuP. CT. REV. 129, 135 (1988) ("[Y]ou have a 'right' to do anything you are not prohibited from doing, and if you have a 'right' to do it, then the state will enforce an obligation upon everyone else to respect your 'right."').

135. Ronald J. Krotoszynski, Jr., Back to the Briarpatch: An Argument in Favor of Constitutional Meta-Analysis in State Action Determinations, 94 Mich. L. REV. 302, 316 (1995); see also Robert W. Gordon, The Elusive Transformation, 6 YALE J.L. \& HuMAN. 137, 148 n.26 (1994) (“Shelley appears to adopt Robert Hale's view that contract rights are a form of delegated state power."); Shelley Ross Saxer, Shelley v. Kraemer's Fiftieth Anniversary: "A Time for Keeping; A Time for Throwing Away"?, 47 U. KAN. L. REV. 61, 65 (1998) ("Shelley blurs the distinction between public acts, which are subject to constitutional restraints as state actions, and private acts, which are not subject to those restraints, by labeling as state action virtually all private acts brought to the court for enforcement.").

136. Edwards v. Habib, 397 F.2d 687 (D.C. Cir. 1968).

137. Id. at 691 (citation omitted).

138. See generally William W. Van Alstyne \& Kenneth L. Karst, State Action, 14 StAN. L. ReV. 3, 53 (1961) ("Most of the courts have resisted the ultimate potential applications of Shelley $v$. Kraemer."); Louis Henkin, Shelley v. Kraemer: Notes for a Revised Opinion, 110 U. PA. L. REV. 473, 477 (1962) (stating that Shelley "cannot stand for a universal proposition that a court cannot enforce a private discrimination if the state could not itself make that discrimination"). 
even though public schools may not. ${ }^{139}$ Private individuals may discriminate on the basis of race in allowing guests on their property even though the state itself may not. ${ }^{140}$ If, therefore, a jury may not rely on race-based tort tables, it is not simply because the state may never enforce or reflect private prejudice. A more nuanced understanding of Shelley is necessary in order to assess whether judicial reliance on race-based tables in tort cases is in fact state action.

\section{B. State Action as Furthering Important Interests}

A second, and more realistic, interpretation of Shelley and its progeny is that state enforcement of private discrimination is unconstitutional only when the private conduct implicates important third-party interests in social or economic participation. Under this view, only state authorization of private conduct that itself substantially undermines the social and economic participation rights of protected group members is subject to constitutional constraint. The interests affected must be highly important in order for the state's authorization of the discriminatory private conduct to trigger constitutional review. Professor Harold Horowitz takes this view of Shelley. According to Horowitz, in deciding "whether the definition and enforcement by a state of legal relations between private persons was unconstitutional state action ... [t]he primary inquiry would be to determine in each case the exact effect on the individual of the particular state action." 141

Certainly there is language in Shelley to support this reading of the case. The Court emphasized the importance of the civil right at stake-namely the

139. See, e.g., Evans v. Newton, 382 U.S. 296, 300 (1966) ("While a State may not segregate public schools so as to exclude one or more religious groups, those sects may maintain their own parochial educational systems.").

140. See Herzog, supra note 123, at 40.

141. Harold W. Horowitz, The Misleading Search for "State Action" Under the Fourteenth Amendment, 30 S. CAL. L. REV. 208, 221 (1957). Horowitz continues to explain:

The cases which have been discussed have illustrated some of the factors which would be considered in deciding whether the definition and enforcement by a state of legal relations between private persons was unconstitutional state action. For example, in the realm of problems dealing with racial discrimination, does the state action compel, or only permit, discrimination against a person because of his race? In what context does the discrimination based on race arise? Does it concern opportunity to purchase or use land, or opportunity to be buried in a particular private cemetery, or opportunity to enjoy the facilities of a public inn or theatre, or opportunity to be benefited by a private or charitable trust or opportunity to vote in public elections?

Id.; see also Alexander, supra note 123, at 902 (explaining that "the reasonableness, not the existence, of state action is the issue in every case involving permissive actions"); Henkin, supra note 138, at 490 (arguing that when the state enforces private conduct the enforcement is not subject to the exact same equal protection requirements as if the state was acting directly because the private privacy interests in some cases are strong enough to outweigh the state's equal protection obligations); Herzog, supra note 123, at 45-46 (explaining that in apparently parallel cases the state does just the same sort of thing, but there is no constitutional violation in sight and noting as an example that "[t]he constitutionality of the law of trespass goes one way when blacks 'intrude' in an amusement park, another when they intrude in a private home"). 
right to participate on equal footing with white people in the economic marketplace - at least suggesting that, had the rights at stake been less important, the Court would not have reached the same decision. The Court explained:

It cannot be doubted that among the civil rights intended to be protected from discriminatory state action by the Fourteenth Amendment are the rights to acquire, enjoy, own and dispose of property. Equality in the enjoyment of property rights was regarded by the framers of that Amendment as an essential pre-condition to the realization of other basic civil rights and liberties which the Amendment was intended to guarantee. ${ }^{142}$

Indeed, the Supreme Court in Shelley probably could have reached its desired outcome-prohibiting state enforcement of racially restrictive covenants - by relying on traditional common law property principles. As Professor Carole Rose has pointed out, both the horizontal privity and touch and concern requirements for treating the covenants as running with the land under common law were problematic in Shelley. ${ }^{143}$ The Court chose instead to frame the case as a constitutional one and to emphasize the fundamental property rights at stake. ${ }^{144}$

Not surprisingly, several lower courts have adopted this view of Shelley. In West Hill Baptist Church v. Abbate, for example, the plaintiff church sought a declaratory judgment holding that enforcement of private covenants was unconstitutional when those covenants limited the use of covered land to residential and agricultural uses and thereby prohibited the construction of houses of worship. ${ }^{145}$ The court agreed with the church that enforcement of the private covenants would violate their First Amendment rights. ${ }^{146}$ In finding such enforcement unconstitutional, the court emphasized the importance of the interest at stake for the plaintiffs. According to the court, "[w]hile it is true, of course, that when the effect of such a covenant upon the exercise of one's

142. Shelley v. Kraemer, 334 U.S. 1, 10 (1948). Similarly, the Court emphasized, "We have noted that freedom from discrimination by the States in the enjoyment of property rights was among the basic objectives sought to be effectuated by the framers of the Fourteenth Amendment. That such discrimination has occurred in these cases is clear. Because of the race or color of these petitioners they have been denied rights of ownership or occupancy enjoyed as a matter of course by other citizens of different race or color." Id. at 20-21.

143. See Carol M. Rose, Property Stories: Shelley v. Kraemer, in PrOPERTY STORIES 169, 180 84 (Gerald Korngold \& Andrew P. Morriss eds., 2004). As Rose explains: "The doctrine of 'horizontal privity' required that no promises or covenants could run with the land and bind future possessors unless the covenants were created in conjunction with a lease or sale of the property." Id. at 180 . The touch and concern doctrine requires that a covenant had to " "touch and concern' land if it were to run." Id. at 182.

144. Shelley, 334 U.S. at 20 (holding that "in granting judicial enforcement of the restrictive agreements in this case, the States have denied petitioners the equal protection of the laws and that, therefore, the action of the state courts cannot stand").

145. 261 N.E.2d 196, 202 (Ohio C.P. Summit Cty. 1969).

146. Id. at 202 (holding that "the enforcement of these covenants which would result in prohibiting the use by the plaintiff and the cross-petitioners of their property for the erection thereon of houses of worship, would constitute state action (through this Court) violative of the free exercise of religion provision of the First Amendment"). 
freedom of religion is small and the public interest to be protected is substantial such freedom is to give way to the public interest, that situation does not here exist." ${ }^{147}$ Similarly in Franklin v. White Egret Condominium, Inc., a Florida state court refused to enforce a condominium's covenant prohibiting children under age twelve from living on the premises. ${ }^{148}$ In holding that state enforcement of the covenant was unconstitutional, the court there too emphasized the importance of the rights burdened by the covenant—in this case landowners' rights to marry and procreate. ${ }^{149}$

This conception of Shelley as focusing on the importance of the rights being burdened by state enforcement of private discrimination also helps make sense of the Court's finding of no constitutionally suspect state action in the cases of Palmer v. Thompson ${ }^{150}$ and Moose Lodge v. Irvis. ${ }^{151}$ In Palmer, the Supreme Court held that the City of Jackson, Mississippi's decision to close its public pools rather than desegregate them, and to permit private citizens to operate the pools on a racially segregated basis, did not violate the equal protection rights of black citizens. ${ }^{152}$ In Moose Lodge, the Supreme Court upheld the state's authorization of individuals to choose members of their own private clubs-even if they did so in a racially discriminatory manner. ${ }^{153}$ In both cases, the Court focused on the trivial or limited nature of the third-party interest at stake as a result of the private discrimination. In Moose Lodge, for example, the Court noted that "Moose Lodge is a private social club in a private building." Palmer, Justice Blackmun explained why he joined the opinion of the Court allowing the pools to be closed by emphasizing, "The pools are not part of the city's educational system. They are a general municipal service of the nice-tohave but not essential variety, and they are a service, perhaps a luxury, not enjoyed by many communities." 155

State enforcement of private prejudice via reliance on race-based wage, life, and work-life expectancy tables implicates precisely the kind of important social and economic interests that should trigger a finding of state action under this reading of Shelley. First, the use of such tables classifies on the basis of race.

147. Id. at 201-02.

148. 358 So. 2 d 1084 (Fla. Dist. Ct. App. 1978).

149. Id. at 1088 ("This restriction is an unconstitutional violation of this defendant's rights to marry and procreate. Further, no compelling reason has been shown for refusing to allow children under twelve (12) to reside in the condominium.").

150. 403 U.S. 217 (1971).

151. 407 U.S. 163 (1972).

152. 403 U.S. at 226 (emphasis omitted) ("[T]he issue here is whether black citizens in Jackson are being denied their constitutional rights when the city has closed the public pools to black and white alike. Nothing in the history or the language of the Fourteenth Amendment nor in any of our prior cases persuades us that the closing of the Jackson swimming pools to all its citizens constitutes a denial of 'the equal protection of the law."').

153. 407 U.S. at $164-65$.

154. Id. at 175.

155. 403 U.S. at 229. 
Racial classifications are at the core of the equal protection doctrine's concern. Racial classifications were at issue in Shelley and in many of the subsequent cases in which courts applied Shelley-like reasoning to find that state enforcement of private prejudice constituted state action. ${ }^{156}$ Second, the substantive interests at stake in tort cases relate directly to the ability of individuals to participate fully and on equal terms in the economic sphere. The lower awards for black victims that result from the use of race-based tables mean that they are not able to overcome or compensate for their injuries to the same extent as white victims. They may not be able to afford equal rehabilitative care, equal skill training, or equal accommodations as are white victims with similar injuries. They suffer, as a result, from poorer health, more constrained job prospects, and weaker housing options than comparably injured white tort victims. In short, discrimination from the past is propelled into the future, disabling and hampering the social and economic success of black tort victims. Certainly, the economic and social participation rights at stake as a result of racially disparate damage awards in tort cases are as significant as the social and economic participation rights called into question by the racially restrictive housing covenants at issue in Shelley.

\section{State Action as Symbolic Encouragement}

A third, and narrower, reading of Shelley focuses not on the state's enforcement of discrete acts of private discrimination but on the state's role in encouraging and promoting widespread social discrimination with respect to important social goods. Under this view, what is critical to finding an equal protection violation stemming from state authorization of private conduct is that the state has itself encouraged and enabled a more sweeping kind of private discrimination than would otherwise exist. The state action as encouragement view of Shelley finds state authorization of private conduct unconstitutional when the state has sent a message encouraging private discrimination that might not otherwise exist. The state may not encourage private discrimination, even through purely symbolic measures, and then use its power to enforce discrimination once it occurs.

Under this view, what was problematic in Shelley was not simply that the state was called upon to enforce private forms of discrimination that significantly impaired black people's social participation, but that the state had itself encouraged community-wide efforts of segregation. The state's willingness to enforce racially restrictive covenants served symbolically to condone and encourage such discrimination. The state could not, then, enforce the private discrimination it had encouraged without violating the Fourteenth Amendment.

156. See Herzog, supra note 123, at 40-41 (noting that "race is different" when it comes to state action analysis). 
This symbolic encouragement conception of Shelley explains why the Supreme Court in Reitman v. Mulkey held that state authorization of private racebased discrimination in residential property sales was unconstitutional. ${ }^{157}$ In Reitman the state of California passed a constitutional amendment permitting property owners to make sale and lease decisions based on any factors they wanted - thereby voiding the state's preexisting statutes prohibiting race-based housing discrimination. ${ }^{158}$ The amendment signaled the state's approval of racebased housing discrimination, and this approval served as a form of encouragement for race discrimination. The amendment changed the status quo, the California Supreme Court noted, from one in which race-based housing discrimination was prohibited "to one wherein it is encouraged." 159 Such encouragement, even if only symbolic, was unconstitutional. As the California Supreme Court explained, "a prohibited state involvement could be found 'even where the state can be charged with only encouraging,' rather than commanding discrimination." ${ }^{\prime 60}$ The United States Supreme Court agreed with both the California Supreme Court's characterization of the amendment and its conclusion regarding the amendment's unconstitutionality. ${ }^{161}$ According to the Court, "Section 26 was intended to authorize, and does authorize, racial discrimination in the housing market. The right to discriminate is now one of the basic policies of the State. The California Supreme Court believes that the section will significantly encourage and involve the State in private discriminations. We have been presented with no persuasive considerations indicating that these judgments should be overturned." 162

157. 387 U.S. 369,373 (1967).

158. The California constitutional amendment challenged in Reitman provided: "Neither the State nor any subdivision or agency thereof shall deny, limit or abridge, directly or indirectly, the right of any person, who is willing or desires to sell, lease or rent any part or all of his real property, to decline to sell, lease or rent such property to such person or persons as he, in his absolute discretion, chooses." Id. at 371 .

159. Id. at 375 (quoting Mulkey v. Reitman, 64 Cal. 2d 529, 542 (Cal. 1966)).

160. Id. at 375 (quoting Mulkey, 64 Cal. $2 \mathrm{~d}$ at 540).

161. Id. at 376 (stating that "[t]here is no sound reason for rejecting this judgment" of the state supreme court regarding the amendment's unconstitutional encouragement of discrimination). The Court approvingly described the ruling of the California Supreme Court as follows:

[The California Supreme Court] did not read either our cases or the Fourteenth Amendment as establishing an automatic constitutional barrier to the repeal of an existing law prohibiting racial discriminations in housing; nor did the court rule that a State may never put in statutory form an existing policy of neutrality with respect to private discriminations .... [I]t held the intent of $\S 26$ was to authorize private racial discriminations in the housing market, to repeal the Unruh and Rumford Acts and to create a constitutional right to discriminate on racial grounds in the sale and leasing of real property. Hence the court dealt with $\S 26$ as though it expressly authorized and constitutionalized the private right to discriminate. Third, the court assessed the ultimate impact of $\S 26$ in the California environment and concluded that the section would encourage and significantly involve the State in private racial discrimination contrary to the Fourteenth Amendment.

Id.

162. Id. at 381 . 
Under this symbolic encouragement conception of Shelley, too, judicial reliance on race-based tables in setting tort damages is state action. By relying on racial distinctions in setting tort damages, courts have encouraged the disproportionate allocation of risk to racial minority communities. They have provided incentives to companies, and indeed whole industries, to concentrate risks in black communities so as to reduce potential liability from what it would be had risks been spread across society more generally. Such disproportionate risk allocation affects individuals' health, longevity and, potentially, career prospects. As a result, through their historical reliance on race-based data, courts have actually encouraged, at least symbolically, the very kind of private race discrimination reflected in the race-based tables being entered into evidence today.

\section{State Action as Facilitation}

The final, and narrowest, reading of Shelley focuses not on the state's symbolic encouragement of discrimination but on the state's functional and material facilitation of it. Under this view, what made state authorization and enforcement of private discrimination unconstitutional in Shelley was that the state had taken concrete steps to overcome the organizational problems which would otherwise have made the discriminatory agreements in the case ineffective.

At its core, the right to contract entails the power to exchange promises and, at a higher level of state involvement, the right to call upon the state to enforce such promises against participants. State enforcement of contracts by and against successor owners who were not part of the original exchange of promises involves a far greater degree of state involvement in private contracts and a move beyond core contract rights. It is this extension of traditional contract rights that made racially restrictive covenants so powerful. Without allowing third-party enforcement of private agreements against successor owners, it is unlikely that individuals would have been able to overcome the free rider problems that plague most attempts at group organization. Individual homeowners would likely violate racially restrictive covenants when faced with sufficiently high offer prices. Third-party enforcement of racially restrictive covenants against successor landowners was critical to the covenants' power and impact. By enforcing restrictive covenants, the state in effect chose to use its power to overcome the problems of private organization. In doing so, the state facilitated a pattern of racial discrimination that otherwise could not have emerged with such depth and sustainability. ${ }^{163}$

163. What is important here is that the state is acting in such a way as to facilitate intentional private discrimination. It does not matter whether the state itself intended to facilitate and encourage such discrimination. There is a similarly narrow version of Reitman that focuses on the state taking concrete steps to facilitate racial housing discrimination by making it impossible for state or local 
Under this view as well, judicial enforcement of private bias through racebased tort tables constitutes state action. Indeed, it was the very enforcement of racially restrictive covenants pre-Shelley that helped establish a pervasive system of racially segregated neighborhoods and schools - the legacy of which continued well after the Supreme Court halted enforcement in Shelley. The state, in other words, through its enforcement of racially restrictive covenants preShelley, facilitated a more pervasive and entrenched form of social segregation than could have existed without state support. While it is certainly true that the state has prohibited discrimination in housing, schools, and health care for over fifty years, the data reflecting lower wages, lower life expectancies, and lower work-life expectancies for black people all reflect, at least to some degree, the history of racial segregation in neighborhoods, schools, and workplaces that the state not only encouraged but facilitated through its enforcement of racially restrictive covenants. ${ }^{164}$

The contours of the state action doctrine - particularly as it relates to state enforcement of private conduct - are far from clear. Nonetheless, under the most plausible interpretations of Shelley and contemporary state action jurisprudence, judicial reliance on race-based wage, life, and work-life expectancy tables to calculate tort damages constitutes state action. To be permissible then, the practice must survive strict scrutiny.

lawmakers to prohibit such discrimination in the future through normal legislative means. As Justice White, writing for the Court, explained:

Private discriminations in housing were now not only free from [existing anti-discrimination statutes] but they also enjoyed a far different status than was true before the passage of those statutes. The right to discriminate, including the right to discriminate on racial grounds, was now embodied in the State's basic charter, immune from legislative, executive or judicial regulation at any level of the state government. Those practicing racial discrimination need no longer rely solely on their personal choice. They could now invoke express constitutional authority, free from censure or interference of any kind from official sources.

Id. at 377; see also Black, supra note 122, at 75 (contending that what the amendment in Reitman does "is to lay a sweeping prohibition on all agencies and subdivisions of government within the state, and not merely on the state legislature, saying that none of them may do anything to place any limitation on the absolute discretion of owners to decline to deal with chosen objects of discrimination among wouldbe buyers and tenants of residential property").

164. See, e.g., Christopher Ramos, The Educational Legacy of Racially Restrictive Covenants: Their Long Term Impact on Mexican Americans, 4 SCHOLAR 149, 165-66 (2001) ("Between the 1910s and the 1940s, courts throughout the nation upheld racially restrictive covenants. The enforcement of these racially restrictive covenants during the 1910s, 1920s, 1930s, and 1940s have had a lasting effect on many Mexican-American communities and the effects of these racially restrictive covenants remain visible."); Leland Ware, The Demographics of Desegregation: Residential Segregation Remains High 40 Years After the Civil Rights Act of 1964, 49 ST. LOUIS U. L.J. 1155, 1166 (2005) (describing the lingering effects of housing segregation resulting from the enforcement of racially restrictive covenants and discrimination and noting that "[b]lack families that are confined to segregated neighborhoods by discriminatory practices reside in areas where schools are inferior, home values are lower, and routine services such as grocery stores and pharmacies are scarce"). 
IV.

\section{SubJeCting Reliance On RACE-BASEd TABLes to StRict SCRUtiny}

"[A]ll racial classifications, imposed by whatever federal, state, or local governmental actor, must be analyzed by a reviewing court under strict scrutiny." classification be "narrowly tailored" to promote a "compelling" state interest in order to pass constitutional muster. ${ }^{166}$ What this looks like in practice is the subject of disagreement and differing interpretations.

\section{A. Strict Scrutiny as a Nearly Categorical Prohibition}

The most common understanding of strict scrutiny among lawyers and lay people is probably that it is a "nearly categorical prohibition." 167 Under this view, strict scrutiny strikes down racial classifications unless they are necessary to "avert imminent catastrophic harms." 168 As Professor Gerald Gunther famously described, strict scrutiny is " strict' in theory and fatal in fact."169

It is indeed the case that the vast majority of laws subjected to strict scrutiny fall under its weight, ${ }^{170}$ and the justices have at times spoken of strict scrutiny in such categorical terms. Justice Scalia, for example, explained in his concurring opinion in City of Richmond v. J.A. Croson Co., that "[a]t least where state or local action is at issue, only a social emergency rising to the level of imminent danger to life and limb ... can justify an exception to the principle embodied in the Fourteenth Amendment that '[o]ur Constitution is color-blind.","171 Justice Thomas has described strict scrutiny in similarly extreme terms explaining that "only those measures the State must take to provide a bulwark against anarchy,

165. Adarand Constructors, Inc. v. Peña, 515 U.S. 200, 227 (1995); see also Hunt v. Cromartie, 526 U.S. 541, 546 (1999) ("“A]11 laws that classify citizens on the basis of race . . . are constitutionally suspect and must be strictly scrutinized.").

166. See, e.g., Johnson v. California, 543 U.S. 499, 505 (2005) (quoting Adarand, 515 U.S. at 227) ("Under strict scrutiny, the government has the burden of proving that racial classifications "are narrowly tailored measures that further compelling governmental interests."'); see also R.A.V. v. City of St. Paul, 505 U.S. 377, 395-96 (1992) (holding ordinance unconstitutional because it was not "reasonably necessary to achieve St. Paul's compelling interests").

167. Richard H. Fallon, Jr., Strict Judicial Scrutiny, 54 UCLA L. REV. 1267, 1302 (2007).

168. Id. at 1303.

169. See Gerald Gunther, Foreword: In Search of Evolving Doctrine on a Changing Court: A Model for a Newer Equal Protection, 86 HARV. L. REV. 1, 8 (1972).

170. See Adam Winkler, Fatal in Theory and Strict in Fact: An Empirical Analysis of Scrutiny in the Federal Courts, 59 VAND. L. REV. 793, 796-97 (2006) (finding that 70 percent of applications of strict scrutiny result in the law being struck down and explaining that "[w]hile it remains true that the majority of laws subjected to strict scrutiny fall and that the government typically faces an onerous task defending laws under this standard, strict scrutiny is not nearly as deadly as generations of lawyers have been taught").

171. City of Richmond v. J.A. Croson Co., 488 U.S. 469, 521 (1989) (Scalia, J., concurring). 
or to prevent violence, will constitute a "pressing public necessity" satisfying strict scrutiny. ${ }^{172}$

Certainly, a court's reliance on race-based tables to calculate damages in torts cases would not pass such a high bar. No "social emergency" would transpire, no violence would occur, if courts were to rely on racially blended rather than racially divided tables to calculate tort damages. Yet the strict scrutiny bar is not always set so high. ${ }^{173}$

\section{B. Strict Scrutiny as a "Smoking Out" Device}

A second, narrower, understanding of strict scrutiny is as a device designed to "smoke out" invidious motives by the state. Under this view, the purpose of strict scrutiny is to uncover illegitimate motives. It is invidious motive that renders state action unconstitutional, not the racial classification itself or even its impact on a traditionally protected group. ${ }^{174}$

On numerous occasions, the Supreme Court has described the purpose and application of strict scrutiny in this way. In Richmond v. J.A. Croson Co., for example, Justice O'Connor's plurality opinion explained that "[a]bsent searching judicial inquiry into the justification for such race-based measures, there is simply no way of determining what classifications are 'benign' or 'remedial' and what classifications are in fact motivated by illegitimate notions of racial inferiority." ${ }^{175}$ Similarly, in Johnson v. California the Court explained, "The reasons for strict scrutiny are familiar. Racial classifications raise special fears that they are motivated by an invidious purpose."

Professor Jed Rubenfeld has argued that this "smoking out" view of strict scrutiny is the only one that makes sense because "[d]etermining whether the relevant state interests are legitimate or illegitimate must precede the application of heightened scrutiny," and classificationism "elides this critical inquiry." ${ }^{177} \mathrm{He}$ concludes, "[a]s a smoking-out device, heightened scrutiny is sensible. As a cost-

172. Grutter v. Bollinger, 539 U.S. 306, 353 (2003) (Thomas, J., concurring in part and dissenting in part).

173. See Fallon, supra note 167, at 1305 (noting that "[f]or better or worse ... the Court has not consistently interpreted the strict scrutiny test as establishing that preferred rights must yield only to cataclysmic threats").

174. Jed Rubenfeld, Affirmative Action, 107 YALE L.J. 427, 443 (1997) (“[S]trict scrutiny ought to be what it always was: a test for smoking out ulterior, unconstitutional state purposes."); see also Fallon, supra note 167, at 1308-10 (describing the view that "strict scrutiny is a test of illicit motives, appropriately applied to ensure that the government has not purposely targeted a protected group or burdened a preferred right”); Kermit Roosevelt III, Constitutional Calcification: How the Law Becomes What the Court Does, 91 VA. L. REV. 1649, 1678-79 (2005) (explaining that "[h]eightened scrutiny ... is a method of allocating judicial scrutiny to those classifications most likely to be invidious").

175. J.A. Croson, 488 U.S. at 493 (plurality opinion).

176. Johnson v. California, 543 U.S. 499, 505 (2005).

177. Rubenfeld, supra note 174, at 437 (emphasis omitted). 
benefit justificatory test, it is indefensible."178 Rubenfeld's focus is the constitutionality of race-based affirmative action by colleges and universities. He contends that the effects of such plans - even if they might be harmful to racial minorities themselves - simply do not matter for the purposes of strict scrutiny. ${ }^{179}$ Because affirmative action plans are not plausibly the product of invidious motives toward white applicants, ${ }^{180}$ he argues that there is no basis for holding such plans unconstitutional. ${ }^{181}$

Were a court to apply such an exclusively motive-focused version of strict scrutiny to the use of race-based tables in torts case, a similar conclusion would follow. Just as Rubenfeld contends that it is implausible to conclude that an invidious motive to harm white applicants drives university affirmative action plans, it is also implausible to conclude that either courts, or the expert witnesses on whom they rely, use race-based tables with the purpose or intention of demeaning and degrading black victims. If motive is all that matters, and classification and effects are irrelevant to strict scrutiny analysis, then it follows that the use of race-based tables by courts in determining tort damages is constitutionally sound. Yet it is clear, as Rubenfeld himself concedes, that the Supreme Court does not equate strict scrutiny exclusively with a search for illicit motive. ${ }^{182}$ Illicit motive may be sufficient to make a racial classification fail strict scrutiny, but it is not necessary. ${ }^{183}$

\section{Strict Scrutiny as a Balancing Test}

On numerous occasions - particularly but not exclusively in cases dealing with affirmative action - the Supreme Court has described and applied strict scrutiny as a kind of balancing test. ${ }^{184}$ Under this view, racial classifications are

178. Id. at 428. Rubenfeld goes on to criticize the Court's shift from a "smoking out" conception of strict scrutiny to a costs and benefits conception on the grounds that "strict scrutiny now serves, expressly and self-consciously, as a justificatory test in which important state interests are permitted to outweigh acknowledged constitutional injuries." Id. at 440. Indeed, Rubenfeld contends that a costbenefit interpretation of the Equal Protection Clause is itself unconstitutional. Id. at 428 .

179. Id. at 445 ("'A]ffirmative action's unintended consequences - including, for example, the stigmatization of minorities - harmful though they may be, are constitutionally irrelevant.").

180. Id. at 461 ("If there is a colorable argument that whites are purposefully reduced to lowercaste status when the proportion of white students at prestigious public universities declines from ninetyfive percent to eighty-five percent, I have yet to hear it.").

181. Id. at 445 (emphasis omitted) ("If affirmative action doctrine is to be consistent with the rest of equal protection law, only an illegitimate racial purpose can render affirmative action unconstitutional.”).

182. Rubenfeld himself recognizes this version of strict scrutiny in the Court's opinions. See id. at 428 ("[U]nder today's affirmative action doctrine, strict scrutiny has become . . . a cost-benefit test ....").

183. See, e.g., Gratz v. Bollinger, 539 U.S. 244, 275 (2003) (holding that the University of Michigan's race-based affirmative action policy for freshman admissions violated the Equal Protection Clause).

184. See, e.g., Emp't Div. v. Smith, 494 U.S. 872, 883 (1990) (describing strict scrutiny as a balancing test in the context of freedom of religion challenges to laws of general applicability); Brown v. Socialist Workers '74 Campaign Comm. (Ohio), 459 U.S. 87, 92-98 (1982) (applying strict scrutiny 
themselves a harm, even if not prompted by invidious motives, and they are unconstitutional if their harm is not outweighed by important, indeed compelling, social benefits. ${ }^{185}$

In Adarand Constructors, Inc. v. Peña, for example, the Court applied strict scrutiny to a federal law providing financial incentives to federal contractors to hire minority-owned businesses as subcontractors. ${ }^{186}$ The Court made clear that strict scrutiny required not simply a search for invidious motive-which certainly was lacking in the case - but a balancing of the costs and benefits of the classification at issue. ${ }^{187}$ As Justice O'Connor explained:

$[\mathrm{W}]$ henever the government treats any person unequally because of his or her race, that person has suffered an injury that falls squarely within the language and spirit of the Constitution's guarantee of equal protection. . . . The application of strict scrutiny, in turn, determines whether a compelling governmental interest justifies the infliction of that injury. ${ }^{188}$

The compelling interest served by the use of race-based tables in tort cases is award accuracy. ${ }^{189}$ Award accuracy is important on the individual level because it ensures adequate compensation for tort victims and avoids undue burdens for tortfeasors. More significantly, it is important on the societal level because it encourages optimal, in the sense of the most economically efficient, levels of social caretaking and risk-avoidance behavior.

When viewed only from the individual level, the state's interest in promoting award accuracy for a particular tortfeasor or victim is not particularly weighty. The use of race-based tables depresses the damage awards that tortfeasors must pay to racial minority tort victims to reflect the likely effects of

as a kind of balancing test to assess a First Amendment freedom of association claim); Nixon v. Adm'r of Gen. Servs., 433 U.S. 425, 467-68 (1977) (describing strict scrutiny in the First Amendment context as a balancing test).

185. See Fallon, supra note 167, at 1306 (citation omitted) ("According to a second interpretation, strict scrutiny is indeed an all-things-considered balancing test, distinguished from other balancing tests by its premise that the stakes on the rights side of the scale are unusually high and that the government's interests must therefore be weighty to overcome them.").

186. Adarand Constructors, Inc. v. Peña, 515 U.S. 200, 226 (1995).

187. Id. at 229-30.

188. Id.; see also Johnson v. California, 543 U.S. 499, 507-08 (2005) (suggesting that strict scrutiny review of prison policy of making initial inmate assignments based on race needed to consider whether the benefits of the practice in terms of avoiding racial violence outweighed its costs); Richardson v. Ramirez, 418 U.S. 24, 78 (1974) (Marshall, J., dissenting) (“'Compelling state interest' is merely a shorthand description of the difficult process of balancing individual and state interests that the Court must embark upon when faced with a classification touching on fundamental rights.").

189. Certainly, such tables do not provide perfect accuracy. No one would claim as much. At most the tables provide a crude guess of how much a tort victim would have earned in the future and how long that person would have lived based on generalizations about how members of the victim's racial group worked and lived in the past. See Chamallas, Civil Rights in Ordinary Tort Cases, supra note 7, at 1452-53 (explaining that work-life tables are often outdated but even if current at the time of trial they are unable to reflect and account for the social and labor force changes likely to occur over the victim's lifetime). 
past and future racial discrimination. Ensuring that a private tortfeasor does not pay more in damages to her victim than she actually caused hardly seems as compelling as, for example, national security, ${ }^{190}$ "safeguarding the physical and psychological well-being of . . . minor[s], ${ }^{, 191}$ remedying past discrimination, ${ }^{192}$ protecting viable fetuses and pregnant women's health, ${ }^{193}$ diversity in higher education, ${ }^{194}$ or "preventing crime by arrestees"195 —all interests that courts have found "compelling" for the purposes of strict scrutiny analysis. While some of these interests may seem more compelling and weighty than others, they all reflect goals and priorities that are more social and public spirited than an interest in ensuring that private tortfeasors pay racial minority victims damages that reflect the worse life chances and narrowed opportunities that members of their racial group have historically had.

It is true that a move from race-based to racially blended tables would depress awards for individual white victims. The state's interest in ensuring that white victims are not marginally undercompensated may be legitimate, but it too does not seem to rise to the level of importance of the broader social interests courts have previously treated as compelling. Moreover, to the extent that the state has a legitimate interest in the adequacy of individual awards for white victims, it is in ensuring that white victims are not undercompensated, not in ensuring that white victims receive greater compensation than black victims. However, the use of race-based tables ensures only the latter. Alternative mechanisms like increased individuation of award predictions, or the adoption of white normed tables for all victims, would serve the former interest without the use of a constitutionally suspect racial classification. ${ }^{196}$

The stronger way to frame the state's interest in the use of race-based tables is to focus not on fairness to individual tortfeasors or victims, but on the benefits to society generally from encouraging an economically optimal level of caretaking behavior. Framed in this way, the state interest at stake with the use of race-based tort tables has, at least nominally, the same public spiritedness of the other interests that courts have treated as compelling. ${ }^{197}$ Yet even if this framing of the state's interest appears "compelling," the benefits won by the use

190. Korematsu v. United States, 323 U.S. 214, 219-20 (1944).

191. New York v. Ferber, 458 U.S. 747, 756-57 (1982) (quoting Globe Newspaper Co. v. Superior Court, 457 U.S. 596, 607 (1982)).

192. Adarand Constructors, Inc. v. Peña, 515 U.S. 200 (1995); City of Richmond v. J.A. Croson Co., 488 U.S. 469 (1989).

193. Roe v. Wade, 410 U.S. 113, 162-63 (1973).

194. Grutter v. Bollinger, 539 U.S. 306, 328 (2003); Regents of the Univ. of Cal. v. Bakke, 438 U.S. 265 (1978).

195. United States v. Salerno, 481 U.S. 739, 749 (1987).

196. In this Article we argue only that the use of race-based tables is unconstitutional without taking a position on the nature of the tables which might replace them.

197. We say nominally here because the optimal level of caretaking that is encouraged by racebased tables distinguishes based on the race of the person potentially being put in danger and for this reason the effect of the tables is not in fact public spirited in our view at all. 
of race-based tables would still need to outweigh the harms in order to survive strict scrutiny. Instead, the harms of using race-based tables not only outweigh the benefits, they actually undercut the very value of economically optimal caretaking as a compelling, or even legitimate, state interest.

In assessing harms for the purposes of strict scrutiny analysis, the Court has focused most explicitly on the fit between the racial classification and its socially beneficial ends - demanding narrow tailoring of the former to the latter. In order to be constitutional, a racial classification must serve the state's compelling state interest while not at the same time being too over- or underinclusive in terms of its scope of coverage. ${ }^{198}$ If, for example, the interest served by a particular racebased affirmative action program is to overcome past discrimination, the program would need to be structured so that it adequately captured and gave a benefit only to those individuals who had been harmed by past discrimination. ${ }^{199}$

In the torts context, race-based tables provide a very poor estimate of the actual losses suffered by any particular victim. The tables used are often outdated. ${ }^{200}$ Even if current, however, they reflect data about the choices and preferences group members have had in the past but do not incorporate or take into account social changes that might lead to different preferences and practices among group members in the future. ${ }^{201}$

The fit between race-based tables and wages is likely to be particularly poor for young black people of high socioeconomic status. Many black child tort victims, particularly those of high socioeconomic status, surely would have achieved wages more similar to those of their white peers than to those of their black ancestors - for whom racial discrimination was far more pronounced and prevalent - or to those of black people of the same generation but of lower socioeconomic status. A study by sociologist Jeremy Pais, for example, found that the racial pay gap between black and white men was larger among those from lower-middle-class and working-class childhood backgrounds than among those from upper-middle-class backgrounds. ${ }^{202}$ Indeed, among those from upper-

198. See Ian Ayres, Narrow Tailoring, 43 UCLA L. REV. 1781, 1786 (1996) ("The idea that a remedy needs to be tailored to further the government's legitimate interest is unexceptional—and is captured by the idea that remedial classifications should not be too overinclusive or underinclusive.").

199. See, e.g., City of Richmond v. J.A. Croson Co., 488 U.S. 469, 506 (1989) (noting that "[i]f a $30 \%$ set-aside was 'narrowly tailored' to compensate black contractors for past discrimination, one may legitimately ask why they are forced to share this 'remedial relief' with an Aleut citizen who moves to Richmond tomorrow?").

200. See Chamallas, Civil Rights in Ordinary Tort Cases, supra note 7, at 1451-53 (explaining that Bureau of Labor Statistics data used to project work-life expectancy is decades old).

201. See Wriggins, Constitutional Law and Tort Law, supra note 7, at 274-75. However, even if these actuarial problems could be solved such that the tables accurately reflected declining trends in societal discrimination, the use of such tables would still fail to satisfy strict scrutiny.

202. Pais assigned respondents from the 1979 National Longitudinal Survey of Youth to a socioeconomic stratum based on their childhood socioeconomic status and then assessed the wage gap between black and white men within each childhood socioeconomic stratum. See Jeremy Pais, Socioeconomic Background and Racial Earnings Inequality: A Propensity Score Analysis, 40 SoC. SCI. RES. 37 (2011). 
middle-class childhood backgrounds there was no racial pay gap. ${ }^{203}$ Pais concluded that "[f]or children raised with class privileges, racial status appears to have little impact on their adult earnings attainment." ${ }^{204}$ Similarly, economists Jonathan Fisher and Christina Houseworth studied data from the 2004 National Sample Survey of Registered Nurses and found that among this educated population, black women had earnings "on par" with those of white women. ${ }^{205}$ Indeed, the authors found that black female nurses earned nine percent more than white female nurses. ${ }^{206}$

Fit is also likely to be poor between race-based data and life expectancy, where class again seems to dominate race when it comes to predictions. ${ }^{207}$ Professor Arline Geronimus and her co-authors found, for example, that "African American residents of advantaged urban areas have substantially higher life expectancies than their poor urban counterparts; in some cases their life expectancies approach the white national average."208 Moreover, many white child tort victims, particularly those of lower socioeconomic status, would likely have had life expectancy outcomes more comparable to those of black people, despite their racial privilege. Indeed, according to Geronimus, "[w]hite residents of urban poor areas have mortality profiles comparable to those of black residents of poor rural areas and blacks nationwide, and somewhat worse than residents of relatively advantaged black urban areas.

203. Id. at 47 ("From this research, it is evident that black men from modest socioeconomic origins experience more difficulty in rising above their lower-middle and working-class backgrounds than do white men from similar socioeconomic beginnings. There is no evidence of an earnings disparity among black and white men from upper-middle-class backgrounds.").

204. Id.

205. Jonathan D. Fisher \& Christina A. Houseworth, The Reverse Wage Gap Among Educated White and Black Women, 10 J. ECON. INEQ. 449, 449 (2012); see also JONATHAN JACOBSON ET AL., NAT'L CTR. FOR EDUC. STATISTICS, EDUCATIONAL ACHIEVEMENT AND BLACK-WHITE INEQUALITY (2001) (finding that for those with similar levels of education, black women earn as much as white women); Dan Black et al., Why Do Minority Men Earn Less? A Study of Wage Differentials Among the Highly Educated, 88 REV. ECON. \& STAT. 300 (2006) (finding that the observed racial wage gap among college-educated men born outside the South was approximately zero); $c f$. Dan A. Black et al., Gender Wage Disparities Among the Highly Educated, 43 J. HuM. RESOURCES 630, 656 (2008) (finding that for Asian and Hispanic women with high labor-force attachment and high levels of education, the gender wage gap relative to white men is essentially zero).

206. Fisher \& Houseworth, supra note 205, at 461. The authors also found that even if they controlled for differing endowments like degree of education and geographic location, black female nurses still earned approximately 7.1 percent more than white female nurses. Id. at 458 .

207. McMillan v. City of New York, 253 F.R.D. 247, 252 (E.D.N.Y. 2008) ("Gross statistical tables do not answer the question: how does the life expectancy of well-off or middle-class 'AfricanAmericans' compare to that of poor 'African-Americans?'”); Arline T. Geronimus et al., Inequality in Life Expectancy, Functional Status, and Active Life Expectancy Across Selected Black and White Populations in the United States, 38 DEMOGRAPHY 227, 241 (2001).

208. Geronimus, supra note 207, at 241; see also McMillan, 253 F.R.D. at 252 (noting that " [t]he impact of socio-economic status (SES) on life expectancy has long been recognized").

209. Geronimus, supra note 207, at 234-35; see also McMillan, 253 F.R.D. at 250 (citations omitted) ("'Racial' and 'ethnic' disparities in quality of health care, for example, remain substantial across a broad range of medical services. But those 'disparities are associated with socioeconomic 
For purely statistical reasons as well, race-based tables cannot be expected to provide accurate loss estimates for any particular tort victim. Race-based tables provide an estimate of the average amount that tort victims with particular characteristics require to be made whole based on an analysis of large populations. Yet, as statisticians David Cooke and Christine Michie explain, "knowledge of group tendencies - even when precise - may not assist accurate evaluation of the individual case. It is a statistical truism that the mean of a distribution tells us about everyone, yet no one." ${ }^{210}$ Indeed, as sample size increases, the strength of the forecast about actual population mean increases, which leads to a narrowing of the 95 percent confidence interval for the mean. ${ }^{211}$ The result of this narrowing, however, is greater confidence in the mean of the underlying population, but a confidence interval that, because it is so narrow, does not actually predict the next individual score well at all. ${ }^{212}$

Professor Sonja Starr offered an illustration of this phenomenon at work in the context of predicting criminal recidivism. Using an example that involved predicting height for women and men, she showed that using a large sample size of four hundred people allowed for a high level of confidence regarding the true mean of the underlying population. ${ }^{213}$ In fact, the 95 percent confidence interval for the mean for men was between 69.6 and 70.4 inches around a true mean of 70 inches, and the 95 percent confidence interval for women was between 64.5 and 65.3 inches around a true mean of 64.9 inches. ${ }^{214}$ Starr explained that while these confidence intervals provided a strong estimate for the true mean of the underlying population, they did not provide a very accurate prediction of the height of the next woman or man taken from the underlying population. In fact, Starr showed that within a four-hundred-person sample, only 13.5 percent of the women in the sample actually had heights that fell between 64.5 and 65.3, the 95 percent confidence interval for the mean. ${ }^{215}$ To restate the truism above slightly differently, means do well at predicting truths about groups, not individuals. ${ }^{216}$

differences and tend to diminish significantly and, in a few cases, to disappear altogether when socioeconomic factors are controlled."').

210. David J. Cooke \& Christine Michie, Limits of Diagnostic Precision and Predictive Utility in the Individual Case: A Challenge for Forensic Practice, 34 LAW \& HuM. BEHAV. 259, 259 (2010) (citations omitted).

211. See Sonja B. Starr, Evidence-Based Sentencing and the Scientific Rationalization of Discrimination, 66 STAN. L. REV. 803, 844 (2014).

212. Id. at 845 (explaining that "while the confidence intervals for the means get much narrower as the sample grows, the individual forecast interval does not").

213. Id. at 844 .

214. Id.

215. Id.

216. Starr explained that to actually predict the height of the next woman with 95 percent confidence, one would have to use the 95 percent forecast interval, rather than the 95 percent confidence interval for the mean, which would result in a much larger range of between of between 59.9 inches and 70.3 inches. Id. All these fit problems are exacerbated by the difficulty, perhaps impossibility in a world of increasing racial mixing, of determining how particular victims should be racially classified in the first place. See McMillan v. City of New York, 253 F.R.D. 247, 249 (E.D.N.Y. 2008) ("Reliance on 
The result of these problems is not only poor fit between race-based data and award accuracy at the individual level, but also poor fit between race-based data and the broader goal of optimizing social caretaking behavior. Because damage awards are likely to over- or underestimate true damages, it is unlikely that in any given case a tortfeasor will bear the true costs of her risky behavior. The result across cases is both over- and under-deterrence of risky behavior.

Yet even if reliance on race-based means could result in overall levels of damages that accurately reflected social losses, those means should still not be used. The harms caused by race-based tables in terms of stereotyping victims and treating them as components of a group rather than as individuals overwhelms and undermines the social goal of achieving optimal levels of caretaking. $^{217}$

The Supreme Court's decision in City of Los Angeles, Department of Water and Power v. Manhart is instructive, though certainly not controlling. ${ }^{218}$ In Manhart, the Court held that the dangers associated with treating individuals based on group stereotypes outweighed the value of economic accuracy and optimization in a social benefit delivery program. ${ }^{219}$ Manhart involved a challenge by female employees to the Los Angeles Department of Water and Power's practice of requiring female employees to make larger contributions to its pension fund than male employees because mortality tables showed that the average female employee lived several years longer than the average male employee. ${ }^{220}$ In order to cover the additional monthly payments that would be made to female retirees as a result, the Department "required female employees to make monthly contributions to the fund which were 14.84 percent higher than the contributions required of comparable male employees." ${ }^{221}$ The result of the higher pension payments was that female employees took home smaller paychecks than did men with similar wages. ${ }^{222}$

In Manhart, the Court emphasized that Title VII made it "unlawful 'to discriminate against any individual." 223 This language, the Court explained, made clear that individuals could not be treated simply as "components" of their group, even if the data about their group was accurate. ${ }^{224}$ Female workers needed to be treated either as individuals, or, as in Manhart, where data about how long each individual female employee would live could not be known during the

\footnotetext{
'race'-based statistics in estimating life expectancy of individuals for purposes of calculating damages is not scientifically acceptable in our current heterogeneous population.").

217. As will be discussed shortly, the use of race-based tables is not the only, or even likely the most precise, way to optimize caretaking behavior.

218. 435 U.S. 702, 705 (1978). Manhart was decided under Title VII of the Civil Rights Act of 1964, not under the Equal Protection Clause.

219. Id. at 708-09.

220. Id. at 705 .

221. Id.

222. Id.

223. Id. at 708 (quoting 42 U.S.C. $\S 2000 \mathrm{e}-2(\mathrm{a})(1)$ (1976)).

224. Id. at $707-08$.
} 
relevant period of employment, female employees needed to be treated the same as male employees. Manhart made clear that the employer's interest in optimizing the accuracy and efficiency of its pension program was defeated by Title VII's demand that employees be treated as individuals rather than "as simply components of a racial, religious, sexual, or national class." 225 Even in the absence of individualized data, sex-based group data simply could not be used. $^{226}$

The wording of the Equal Protection Clause differs from that of Title VII, but it too emphasizes that no state shall "deny to any person . . . the equal protection of the laws." ${ }^{227}$ It is individuals who are entitled to equal protection. ${ }^{228}$ Moreover, as with Title VII, the Equal Protection Clause protects individuals most stringently from particular types of group classifications - namely those based on race and sex. ${ }^{229}$ It follows then that under the Equal Protection Clause, as under Title VII, the harms in terms of encouraging racial stereotypes outweigh the state's interest in using even accurate group data to promote an economically efficient system of recovery for tort injuries.

The Equal Protection Clause's fit analysis also includes a least restrictive means test requiring that the state show that there are no practicable race-neutral means by which to serve the same state interest. ${ }^{230}$ In the torts context, that is almost certainly not the case. The future earnings, life, and work-life

225. Id.

226. See Ariz. Governing Comm. for Tax Deferred Annuity and Deferred Comp. Plans v. Norris, 463 U.S. 1073, 1081 (1983) (prohibiting an employer from offering retirement benefits that paid women lower monthly benefits than men based on sex-based actuarial tables and explaining that "the classification of employees on the basis of sex is no more permissible at the pay-out stage of a retirement plan than at the pay-in stage").

227. U.S. CONST. amend. XIV, $\S 1$.

228. See Adarand Constructors, Inc. v. Peña, 515 U.S. 200, 227 (1995) (explaining that "the Fifth and Fourteenth Amendments to the Constitution protect persons, not groups").

229. See, e.g., Kenji Yoshino, The New Equal Protection, 124 HARV. L. REV. 747, 757 (2011).

230. Grutter v. Bollinger, 539 U.S. 306, 339 (2003) ("Narrow tailoring does not require exhaustion of every conceivable race-neutral alternative .... Narrow tailoring does, however, require serious, good faith consideration of workable race-neutral alternatives."); Wygant v. Jackson Bd. of Educ., 476 U.S. 267, 280 n.6 (1986) ("The term 'narrowly tailored,' so frequently used in our cases, has acquired a secondary meaning. More specifically, as commentators have indicated, the term may be used to require consideration of whether lawful alternative and less restrictive means could have been used."); Regents of the Univ. of Cal. v. Bakke, 438 U.S. 265, 357 (1978) (Justices Brennan, White, Marshall \& Blackmun, JJ., concurring in the judgment in part and dissenting in part) ("[A] government practice or statute which restricts 'fundamental rights' or which contains 'suspect classifications' is to be subjected to 'strict scrutiny' and can be justified only if it furthers a compelling government purpose and, even then, only if no less restrictive alternative is available."); see also Ayres, supra note 198, at 1787 ("In essence, before implementing a racial classification, Croson requires policymakers to find that race-neutral means could not achieve the government's compelling interest."); Fallon, supra note 167, at 1326 ("The first element of the narrow tailoring requirement insists that infringements of protected rights must be necessary in order to be justified. The Supreme Court sometimes expresses essentially the same demand when it says that the government's chosen means must be 'the least restrictive alternative' that would achieve its goals. A law would not be necessary to achieve its ends if the government could accomplish the same result while inflicting lesser burdens on protected rights."). 
expectancies of even child tort victims could be predicted by making generalizations based on the education level of the child's parents, the socioeconomic level of the family, and the geographic region where the child lives. ${ }^{231}$ It is likely that these formally race-neutral means of assessing lost wages would serve the narrow goals of award accuracy, and hence the broader goal of optimizing social caretaking levels at least as well as the use of race-based tables. ${ }^{232}$ While their use might be more administratively complex and costly than the use of race-based tables, which are more readily accessible, such increased burden does not shield the state from the obligation to use non-racebased means, when possible. Indeed, as the Court explained in Gratz $v$. Bollinger, "the fact that the implementation of a program capable of providing individualized consideration might present administrative challenges does not render constitutional an otherwise problematic system." 233

In short, the use of race-based tables is not necessary to "avert imminent catastrophic harms, ${ }^{, 234}$ as is required by the near-categorical prohibition view of strict scrutiny. Nor does the use of such tables satisfy the more modest balancing interpretation of strict scrutiny. Even if the promotion of economically optimal caretaking levels were deemed a compelling state interest, the fit between racebased tables and award accuracy is too poor, and less restrictive means to serve the same goal are too available for the use of race-based tables to survive strict scrutiny.

V.

\section{IMPLICATIONS}

We have argued in the last three Sections that the use of race-based tables is unconstitutional. In this Section we return to the core policy and social justice concerns raised in Part I to assess the extent to which these concerns would in

231. See McMillan v. City of New York, 253 F.R.D. 247, 252 (E.D.N.Y. 2008) ("Given the significant impact of socio-economic factors, it is natural for courts to be concerned with the use of life expectancy tables that ignore important distinctions such as education, place of residency, and employment, collapsing all members of a 'racial' group into a single number.").

232. See Fisher \& Houseworth, supra note 205, at 449; Pais, supra note 202; see also McMillan, 253 F.R.D. at 252 (quoting Geronimus, supra note 207, at 227) ("Reliable studies have found that 'the relationships between socioeconomic position or race/ethnicity and health may be modified by geographic influence and community conditions that contextualize and structure these relationships."'); Geronimus, supra note 207, at 244 ("Our analyses revealed heterogeneity in length and quality of life within the black and the white populations with respect to their communities' economic characteristics and, to some extent, the location of their residence.").

233. Gratz v. Bollinger, 539 U.S. 244, 275 (2003). However, even if a less restrictive alternative were not available, the use of such tables should still fail narrow tailoring because of their over- and underinclusiveness. See Fallon, supra note 167, at 1328 ("Whereas the least restrictive alternative formulation invites the conclusion that a regulation that is necessary to promote a compelling governmental interest will therefore satisfy strict scrutiny as long as no narrower regulation would suffice, the prohibition against overinclusiveness suggests that a statute might be condemned for lack of narrow tailoring.").

234. Fallon, supra note 167, at 1303. 
fact be eliminated or mitigated by courts' rejection of race-based tables. In order to help us think through how individual awards might differ and how social incentives might change in a world without race-based tables, we present a series of hypotheticals.

Consider first a three-year-old black girl named Ann who was seriously injured in a car accident. Ann lives with her mother and father in Brentwood, a wealthy suburb of Los Angeles. Both of her parents are doctors and her two older siblings attend private school. Before her injury, Ann was enrolled in a local preschool and was expected to attend the same private K-12 school as her siblings. In calculating damages for Ann, the court rejects the use of race-based tort tables. As a result, her damage award will not be tainted or depressed by the racism and discrimination experienced by generations of black people before her. Race will be neither salient nor predictive for her in calculating damages. Instead, her damages are likely to be comparable to those that a white neighbor with similar injuries would receive.

Compare Ann with Beth, another three-year-old black girl who also suffered debilitating injuries in a car accident. Beth lives in Compton, a poor neighborhood in Los Angeles. She lives with her mother and grandmother. Beth's mother became pregnant with her at sixteen and dropped out of high school as a result. She struggles to find work. Beth's father was also in high school when she was born, and he too failed to finish. He works intermittently in construction. Beth's father visits her about once per month and usually brings her clothes or a stuffed animal. He does not provide any other financial support. In calculating damages, Beth's judge, too, rejected the use of race-based tort tables. For Beth, like Ann, the rejection of race-based tables means that predictions about her future proclivities will not be made based on her race per se.

Nonetheless, Beth's award will take into account the fact that her parents did not graduate from high school, that she is growing up in a poor neighborhood, and that her local public schools are failing. Moreover, the racial discrimination suffered by her parents - and grandparents - will become embedded in her award as consideration of their educational and job achievements are used as predictors of her own. Beth, as a result, will receive significantly less damages than Ann even if her injuries are identical.

Next consider Charlie, a twenty-one-year-old black male who, like Ann and Beth, was injured in a debilitating car accident. At the time of the accident, Charlie was a senior majoring in chemical engineering at an elite university, with plans to attend graduate school for a Ph.D. in engineering. The judge in Charlie's case rejected the use of race-based tables. Charlie's life prospects will not, as a result, be cabined by predictions about what kind of career he would have had or the life he would have led because of his race. Instead, Charlie's damage award will reflect his bright future and ambitious career prospects. 
Finally, consider David, another twenty-one-year-old black male who was injured in a car accident. David, like Charlie, had hoped to become an engineer. His big rural high school was decent, but it was also highly segregated by race, and he was discouraged from taking advanced science classes. Instead of attending a four-year college, David received an Associate's degree at a local community college. At the time of the accident, David worked as a hospital orderly. The judge in David's case, too, rejected the use of race-based tables. Predictions about David's preferences, disposition, or potential cannot therefore be made based on his race per se. Nonetheless, David's award will reflect and be depressed by the racial discrimination that he himself suffered as a child and young adult. ${ }^{235}$ The fact that David attended a racially segregated school, was discouraged from taking science classes, and had his career prospects narrowed as a result will diminish the amount of his damages. David will receive significantly less damages than Charlie even if his injuries are identical.

The purpose of this discussion is not to undercut the importance of doing away with race-based tables in calculating damage awards. Certainly, eliminating the use of race-based tables will diminish the direct salience of race in tort cases and will weaken the link between proclivity assumptions and race per se. We do mean, however, to be realistic about what such a change would and would not do. Excluding race-based data from use in calculating tort damages will not result in damages that are entirely free of the taint of racial discrimination, either as manifested in the form of generational disparities in healthcare, education, and wealth, or as suffered at the individual level-in the form of prior acts of discrimination and exclusion suffered by the tort victim. As a result, it is unlikely that ending the use of race-based tables will itself end racial disparities in tort damages. It follows that it is similarly unlikely that ending the use of race-based tables will eliminate the social incentive to disproportionately allocate risks to minority communities.

\section{CONCLUSION}

This Article has taken aim at a practice so deeply entrenched in tort litigation as to be almost invisible. Yet it is a practice with harmful consequences that are both broad and deep. It is also unconstitutional.

The goal of this Article is most directly to empower judges with a rich constitutional argument to follow the lead of Judge Weinstein and declare the use of race-based tables in tort cases unconstitutional. But the Article's implications go beyond race and beyond traditional tort litigation. The constitutional arguments made here strongly suggest that the use of sex-based wage, life, and work-life expectancy tables would also fail under the Court's heightened intermediate scrutiny standard articulated in United States $v$.

235. His award will also reflect the effects of racial discrimination suffered directly by his parents and other ancestors. 
Virginia. ${ }^{236}$ The arguments suggest, too, the vulnerability to constitutional attack of state laws sanctioning the use of race- and sex-based tables by private insurers. The changes called for, both directly and by implication, are profound.

Yet on another level, the doctrinal arguments made here are more modest. They do not challenge the idea that the value of people's injuries and indeed their lives differs depending on their earning potential. They do not challenge the practice of grouping individuals based on particular characteristics and assigning damages based on what those characteristics predict about future earnings and life expectancy. They do not in other words, at least not directly, challenge the fundamental underpinnings of tort law. ${ }^{237}$ As a result, eliminating the use of racebased tables in tort damage calculations is not itself sufficient to eliminate racial disparities and racial discrimination from the tort system. It is, however, a necessary first step, and one that we have argued is constitutionally required.

236. 518 U.S. 515, 531 (1996) ("Parties who seek to defend gender-based government action must demonstrate an 'exceedingly persuasive justification' for that action.").

237. See generally Richard L. Abel, A Critique of Torts, 37 UCLA L. REV. 785, 803 (1990) ("Tort law proclaims the class structure of capitalist society: you are what you own, what you earn, and what you do.”); Ellen S. Pryor, Rehabilitating Tort Compensation, 91 GEO. L.J. 659, 660-61 (2003) (explaining that while there is a diversity of theoretical views about what compensation should mean, "a dominant theme in both the theoretical realm and the day-to-day workings of tort law" is that compensation "is the payment of a sum of money that will restore the plaintiff to the status quo ante"); Mark A. Glick, The Law and Economics of Tort Damages, UTAH B.J., Aug.-Sept. 1996, at 8, 9 (noting that " $[t]$ he focus of the damage phase in most accident cases is lost income"). 